\title{
Neo-Austrian Views of the Global Financial Crisis and Its Pre-Corona Aftermath*
}

\author{
Karl Farmer ${ }^{1,2}$, Laurie Conway ${ }^{1}$ \\ ${ }^{1}$ University of Graz, Graz, Austria \\ ${ }^{2}$ University Cluj-Napoca, Cluj-Napoca, Romania \\ Email:karl.farmer@uni-graz.at
}

How to cite this paper: Farmer, K., \& Conway, L. (2021). Neo-Austrian Views of the Global Financial Crisis and Its PreCorona Aftermath. Modern Economy, 12, 712-763.

https://doi.org/10.4236/me.2021.124036

Received: February 4, 2021

Accepted: April 11, 2021

Published: April 14, 2021

Copyright $\odot 2021$ by author(s) and Scientific Research Publishing Inc. This work is licensed under the Creative Commons Attribution International License (CC BY 4.0).

http://creativecommons.org/licenses/by/4.0/

(c) (i) Open Access

\begin{abstract}
In the aftermath of the Global Financial Crisis (GFC) 2007/2008 the sales of Hayek's (1944) Road to Serfdom quadrupled, a clear indication of renewed public interest in the views of (neo-) Austrian economists on macro-economic crises, especially financial crises. It is also true that several economists associated with the Austrian school, or those using neo-Austrian insights, correctly predicted the U.S. housing bubble and the subsequent GFC, apparently, a clear vindication of (neo-) Austrian cycle theory (Hunter, 2018). More surprising is that even relatively fierce opponents of neo-Austrian macro-theory have meanwhile begun to accept some Austrian insights. We thus ought to ask, what are the basic tenets of the Austrian Business Cycle Theory (ABCT) and how did it enable some economists to correctly predict the U.S. subprime crisis and its aftermath? In contrast, it is also true that mainstream macro-economists, although struggling heavily to come up with a suitable theoretical explanation of the GFC, neither accept the neo-Austrian explanation of crises, nor its policy implications. Therefore, we also need to ask why mainstream economists dismiss ABCT. Is it the alleged neo-Austrian bias towards the supremacy of an unfettered market economy which is rejected by the mainstream, or is it rather the lack of correspondence between $\mathrm{ABCT}$ and the stylized facts of business cycles, such as the positive correlation between consumption and investment? We also need to ascertain to what extent the basic Mises-Hayek cycle theory can be applied to an explanation of the U.S. subprime crisis and the GFC? For example, the neo-Austrian economist Salerno (2012: p. 41) has stated that the unprecedented monetary inventions by the U.S. Federal Reserve (Fed) and the enormous government deficits run by U.S. administrations since the Great Recession (GR) must at some point
\end{abstract}

\footnotetext{
${ }^{\star}$ We are grateful to an anonymous referee for very helpful comments on to improve an earlier ver-
} sion of this paper in style and substance. 
lead to a 1970s-style period of stagflation. Why has this failed to materialize? We have currently experienced the longest boom in the U.S. economy since the GR, a boom which has been engineered by anti-Austrian ultra-loose monetary policy. How do neo-Austrian authors manage to cope with such a fact? Such are the research questions dealt with in the following paper. Following an introduction to the main topic, the basic elements of ABCT are presented. Then, neo-Austrian extensions of basic ABCT are applied to an explanation of the U.S. housing bubble and the subsequent GFC. This is followed by discussion of radical neo-Austrian critiques of the unconventional monetary policies used to reflate the U.S. economy after the GR. The main question here is why such policies can continue without producing an economic downturn or bust. The paper concludes with a summary of neo-Austrian views on the GFC and its pre-Corona aftermath.

\section{Keywords}

Financial Crisis, Neo-Austrian Economics, Austrian Business Cycle Theory, Unconventional Monetary Policy, Deflation

\section{Introduction}

Deep financial crises entailing widespread bank credit, such as the Global Financial Crisis (GFC) 2007/2008, are often seen as being the result of unfettered capitalism. This then leads to calls for some form of regulatory intervention, either by the state, or by some other 'big player' such as the central bank. In the aftermath of such crises, it is no surprise, for example, that in former East Germany, thirty years after the fall of the Berlin wall, those calling for a return to communism or a rebirth of socialism (with a green face of course) are now gaining in elections. Thirteen years after the GFC, general approval of free markets appears to be at an historical low, particularly among Western millennials who now seem to favor soft forms of socialism. Such anti-capitalist preferences can to some extent be explained away, at least as far as the young are concerned, as stemming from a lack of experience regarding the historic evils of socialism. However, it is still somewhat surprising that apparently otherwise reasonable people in the media or politics can remain so blind to the potential disadvantages of heavy socialist intervention, either in housing or in other sectors of the economy. Although the current divergence in political opinion, towards both the extreme left and the extreme right can be traced back to a number of complex socio-economic issues, one clear reason for the trend is the prevailing, rather one-sided, analysis of the origin and economic nature of the GFC and its pre-Corona aftermath. According to this mainstream view the GFC was an example of a massive market failure due to the inherent instability of private capitalism, a failure which was triggered by the liberalization of international capital transactions in the 1980s and the national deregulation of financial markets in the late 1990s (e.g. in the 
U.S.A.). As a consequence, in the aftermath of the GFC and subsequent Global Recession (GR) 2008/2009, the U.S. federal government (Treasury) purchased "troubled assets" (mainly in housing) from banks and financial institutions, and US legislators re-regulated the financial sector through the Dodd-Frank Act and the Consumer Protection Act. Moreover, global central banks, acting in tandem, massively reduced bank rates and implemented an unconventional monetary policy by buying troubled assets and government bonds from banks. This renunciation of traditional monetary policy was justified by the former president of the US Federal Reserve System, Ben Bernanke, by attributing the GFC to a "global saving glut" (Bernanke, 2005). While a majority of well-known economists follow Bernanke's explanation of the crisis there is still a stubborn minority of economists who oppose the saving glut hypothesis. In fact, there seems to be growing support, among economists and the general public alike, that the savings glut hypothesis is inadequate and needs to be augmented. One such augmentation can be found in the work of a group of heterodox economists from the Austrian or Vienna School of economic thought, its main representatives being Ludwig von Mises and Friedrich August von Hayek.

Thus, it comes as no surprise that in the aftermath of the Global Financial Crisis (GFC) 2007/2008 the sales of Hayek's (1944) Road to Serfdom quadrupled, a clear indication of renewed public interest in the views of (neo-) Austrian economists on macro-economic crises, especially financial crises. It is also true that several economists associated with the Austrian school (e.g. Shostak, 2003; Thornton, 2003; Karlson, 2004), or those using neo-Austrian insights (e.g. White, 2006), correctly predicted the U.S. housing bubble and the subsequent GFC, apparently, a clear vindication of (neo-) Austrian cycle theory (Hunter, 2018). More surprising is that even relatively fierce opponents of neo-Austrian macro-theory, such as Paul Krugman (2005) have meanwhile begun to accept some Austrian insights. We thus have to ask, what are the basic tenets of the Austrian Business Cycle Theory (ABCT) and how did it enable some economists to correctly predict the U.S. subprime crisis and its aftermath? In contrast, it is also true that mainstream macro-economists, although struggling heavily to come up with a suitable theoretical explanation of the GFC (e.g. Blanchard, 2009), neither accept the neo-Austrian explanation of crises, nor its policy implications. Therefore, we also need to ask why mainstream economists dismiss ABCT. Is it the alleged neo-Austrian bias towards the supremacy of an unfettered market economy which is rejected by the mainstream, or is it rather the lack of correspondence between $\mathrm{ABCT}$ and the stylized facts of business cycles, such as the positive correlation between consumption and investment (e.g. Krugman, 1998; Cowen, 2008; DeLong, 2008; Caplan, 2008)? We also need to ascertain to what extent the basic Mises-Hayek cycle theory can be applied to an explanation of the U.S. subprime crisis and the GFC? For example, the neo-Austrian economist Salerno (2012: p. 41) has stated that the unprecedented monetary inventions by the U.S. Federal Reserve (Fed) and the enormous government deficits run by 
U.S. administrations since the Great Recession (GR) must at some point lead to a 1970s-style period of stagflation. Why has this failed to materialize? Up to the outbreak of the Corona pandemic we have experienced the longest boom in the U.S. economy since the GR, a boom which has been engineered by anti-Austrian ultra-loose monetary policy.

Such are the research questions that need to be dealt with in the present paper. Its main intention is not original neo-Austrian research but an informed overview of the original Mises (1912/1934) and Hayek (1931/1935) business cycle theory and recent neo-Austrian extensions and modifications of the original such that the GFC and its pre-Corona aftermath can be adequately dealt with. In pursuing this objective, we first have to review the basic elements of "canonical" (Young, 2012/2015: p. 6). ABCT and present the mainstream critiques of Haberler's (1937/1963) version of canonical ABCT which is often used by mainstream critics to point out the internal contradictions and hence the irrelevance of the canonical ABCT. We then draw on Young's (2012/2015) extension of Garrison's (2001) graphical exposition of canonical ABCT in order to be able to explain the peculiar events of the housing bubble and the subsequent GFC. In addition, Salerno's (2012) introduction of wealth effects into the basic ABCT is also used to cope specifically with the U.S. retail slump of 2008/2009 during the GR. Complementary applications of ABCT to the subprime crisis, by Ravier and Lewin (2012) and Fillieule (2013), are then contrasted with the explanations offered by mainstream economists. This is followed by a discussion of the neo-Austrian "deflationist" (Fillieule, 2016) critique of the Fed's post-crisis management and is contrasted with Bernanke's (2002) defense of the Fed's reflation policy subsequent to the bursting of the dot-com bubble. In contrasting neo-Austrian financial crises insights and monetary policy views with mainstream explanations an attempt to cross-fertilization concerning the GFC and its pre-Corona aftermath is made. The discussion is rounded off by addressing neo-Austrian responses to the question of why, after more than a decade-long boom engineered by the Fed's lowinterest rate and unconventional monetary policy, there has not been a major downturn in the US economy (as neo-Austrian theory would lead us to expect). The paper concludes with a summary of neo-Austrian views of the GFC and its pre-Corona aftermath.

\section{2. "Canonical" Austrian Business Cycle Theory and Its Mainstream Critics}

ABCT is an economic theory developed by the third generation (Mises, Hayek) of the Austrian School of economics, a school founded by Carl Menger (1871/2004), and subsequently developed by Eugen von Böhm-Bawerk (1890/1959) and Friedrich von Wieser (1926/1927) (second generation). The theory attempts to illustrate how and why unsustainable booms occur, and why they are inevitably followed by a period of decline, or 'bust' (Horwitz, 2012). The theory views business cycles as the consequence of excessive growth in bank credit, due to artifi- 
cially low interest rates set by a central bank and/or fractional reserve banks. The "canonical" ABCT originated in the work of Ludwig von Mises (1912/1934; 1949) and Friedrich August von Hayek (1931/1935; 1933). Hayek won the Nobel Prize in economics in 1974 (shared with Gunnar Myrdal), in part, for his work on ABCT.

At one level, canonical ABCT is clear and easy to comprehend. ${ }^{1}$ The core idea is that changes in the interest rate alter the structure of production. Lower interest rates encourage more roundabout (capital-intensive) methods of production (von Böhm-Bawerk, 1890/1959), and higher interest rates less roundabout methods of production. Interest changes driven by the altered time preference of households lead to corresponding changes in the structure of production. However, artificially low interest rates, arising from excessive bank credit creation, incentivize the adoption of more-roundabout methods of production even though there has been no change in intertemporal households' preferences and this provokes a more volatile and unstable imbalance between saving and investment. Low interest rates tend to stimulate borrowing from the banking system. This leads to an increase in consumption and capital spending funded by newly issued bank credit. However, when the market interest rates rise, for example, because the central bank is attempting to fight consumer price inflation, the credit-sourced boom results in both widespread overconsumption and "malinvestment" (Mises, 1912/1934; Salerno, 2012: p. 15). The change in the structure of production thus represents a misallocation of resources. When the credit creation has run its course, a correction or "credit crunch" occurs-commonly called a "recession" or "bust" - causing a painful reallocation of resources back towards uses consistent with the unhampered adoption of intertemporal consumer preferences, producer technologies and individual wealth distribution.

Thornton (2018) uses the example of skyscraper construction in order to illustrate canonical ABCT (see Hendrickson, 2019/2020). Thornton details how low interest rates increase the present value of investment projects in skyscrapers and thus reduce the cost of capital for firms. The lower cost of capital encourages firms to expand in order to capitalize on economies of scale. In addition, the lower interest rates increase the present value of the flow of services from land. The price of land rises in response. Moreover, the higher price of land encourages building vertically rather than horizontally because the per floor cost of building the taller building is lower. In the construction of taller buildings, production is necessarily more roundabout because taller buildings create problems and issues that would be absent from the construction of smaller buildings.

In line with Young's more theoretical exposition (Young, 2012/2015: pp. 612), canonical ABCT starts with the observation that the production of goods ${ }^{1}$ On closer scrutiny finer details of the theory can become somewhat elusive. For example, one may ask why does production become more roundabout at lower interest rates? Why are entrepreneurs, firms and households systematically fooled by artificially low interest rates? How might one measure production's degree of roundaboutness? What about the empirical evidence regarding malinvestment and overconsumption during the U.S. credit-fueled boom in the period 2001-2006? While these questions cannot be addressed in the present paper, they are dealt with in Horwitz (2016). 
and services is time-consuming, and that it occurs in a series of stages of production. Natural and man-made resources pass from firm to firm as they are transformed from raw materials into intermediate goods and then into finished goods. In the earlier or higher stages of production, producer goods must be produced that will later be needed in producing other producer goods which are themselves needed in subsequent production in the later or lower production stages for the desired consumer goods. How much time production consumes depends on available technologies and consumer preferences. Regarding technologies, more roundabout (time-consuming) methods of production (with a longer average production period (APP $)^{2}$ ) lead to greater returns from production processes than more direct ones (von Böhm-Bawerk, 1890/1959). On the other hand, people value time, i.e. they discount tomorrow. Thus, people face a trade-off between more goods later (which are less valuable) and fewer goods today (which are valued more). Profit-seeking entrepreneurs act upon consumers' perceptions of these intertemporal trade-offs vis-à-vis market prices and market interest rates. The latter represent the relative prices of present versus future goods. Alert entrepreneurs "discover discrepancies between the present prices of the complementary factors of production and the anticipated prices of the products minus the rate of interest" (Mises, 1949: p. 547). A higher market interest rate signals a higher price for current goods relative to future goods, reflecting both a high time preference on the part of the marginal consumer, and a high expected productivity of roundabout production on the part of the marginal investor. The latter strives to obtains funds from savers in order to be able to cover investment costs. Free market interest rates will tend towards expressing the trade-off "between the productivity gains from waiting and consumers' time preferences." (Young, 2012/2015: p. 9).

If, however, market interest rates are regulated by some form of policy, and therefore do not accurately express the underlying trade-offs of savers and investors, funds will be allocated in ways which are inconsistent with consumers' time preferences and the productivity of roundabout production processes. In the case that a central bank increases the supply of base money by lowering the bank rate and the banking system increases credit supply and lowers market interest rates below the free market rate (="originary" (Mises, 1949) or "natural" (Wicksell, 1898/1936)) interest rate), entrepreneurial (=profit-seeking) investors interpret the lower market interest rate as signaling the readiness of consumers to exchange more present goods for future goods. Lower interest rates mean that more roundabout production ventures appear to be more profitable: Investors are led to expect that the demand for future goods has increased. Here, a discrepancy between the investment plans of entrepreneurs and consumers' saving plans becomes obvious: the former outstrip the latter. Moreover, investment plans are executed over time since the production and installation of capital

${ }^{2}$ Financial foundations for von Böhm-Bawerk's (1890/1959) rather controversial concepts of roundaboutness and APP are provided by Cachanosky and Lewin (2016a). 
goods take time. They involve goods of both earlier and later stages of production. The fact that at any one time the higher-stage goods for an investment are available does not imply that the lower-stage goods needed to complete the investment tomorrow will in fact be ready tomorrow. However, as bank credit is first used by entrepreneurs to purchase goods of higher stages of production, the prices of those goods rise relative to the prices of (investment and consumption) goods of lower stages of production. This vindicates the entrepreneurs' interpretation that the lower market interest rates are policy induced.

As credit-funded investment continues, rising income is generated for the producers of goods in higher stages of production. Since the intertemporal preferences of these income earners has not really changed, a larger income enables them to spend more on goods of lowest stages of production. This leads to an increase in the prices of lower-stage consumer goods and is exacerbated by the lower-stage demand for investment goods by the entrepreneurs meeting the lower-stages consumer goods demand. As the prices of lower-stages investment goods rise, the completion of investments started during the boom becomes unprofitable. Investments which initially appeared to be profitable at the start of the boom, now turn out to be "malinvestments" (Mises, 1912/1934). These incomplete investments are abandoned along with the resources employed with them. The period of excessive business lending by banks, i.e. the credit expansion after the turning point of the cycle ${ }^{3}$ is followed by a sharp contraction and a period of distressed asset sales (liquidation). The reallocation of resources towards a sustainable production structure is painful because the production structure is highly complex, containing capital components which are heterogeneous and largely process-specific. Investments in higher-stage goods during the boom are not easily transformed into less roundabout production processes. $\mathrm{ABCT}$ concludes that the longer the increased proportion of spending in higher-stage goods industries continues, the more violent and disruptive will be the necessary re-adjustment process.

In contrast to mainstream economists Mises and Hayek argue that a boom initiated by artificially lowered market interest rates is in fact a period of wasteful malinvestment. "Real" savings would have required higher interest rates to encourage depositors to save their money in term deposits in order to be invested in longer term projects under a stable money supply. According to Mises (1912/ 1934), the artificial stimulus caused by bank lending causes a generalized speculative investment bubble which is not justified by the long-term factors of the market. According to Mises, a "crisis" (or "credit crunch") arrives when the consumers attempt to reestablish their desired allocation of saving and consumption at prevailing interest rates. Mises (1949) claimed that the "recession" or "depression" is actually the process by which the economy adjusts to the wastes and errors of the monetary boom and reestablishes efficient servicing of sustainable consumer desires.

${ }^{3}$ Evans et al. (2019) came up with a new interpretation of the turning point in ABCT within a fiat monetary regime. 
Mises (1949) also argued that continually expanding bank credit can keep the artificial credit-fueled boom alive (with the help of successively lower interest rates from the central bank). This postpones the "day of reckoning" and defers the collapse of unsustainably inflated asset prices. Canonical ABCT argues that the monetary boom ends when bank credit expansion finally stops, i.e. when no further investments can be found which provide adequate returns for speculative borrowers at prevailing interest rates. Canonical ABCT further claims that the longer the "false" monetary boom goes on, the bigger and more speculative the borrowing, the more wasteful the errors committed and the longer and more severe will be the necessary readjustment in the form of bankruptcies, foreclosures, and depression.

ABCT does not maintain that fiscal restraint or "austerity" will increase economic growth or result in recovery (Rothbard, 1963/2000). Rather, it is argued that the alternatives will make eventual recovery more difficult and unbalanced. All attempts by "big players" such as central banks and central governments to prop up asset prices, bail out insolvent banks, or "stimulate" the economy with deficit spending will only make the misallocations and malinvestments more acute and the economic distortions more pronounced, thus prolonging the depression and adjustment necessary to return to stable growth. (ibid) According to $\mathrm{ABCT}$, the policy error derives from the government's (and central bank's) weakness or negligence in allowing the "false" unsustainable credit-fueled boom to begin in the first place, not in having it end with fiscal and monetary "austerity". Debt liquidation is therefore the only solution to a debt-fueled problem. According to Mises (1949) there is no means of avoiding the final collapse of a boom brought about by credit expansion. The question is only whether the crisis should come sooner as a result of the voluntary abandonment of further credit expansion, or later, in the form of a final and total collapse of the currency system.

Neo-Austrians (e.g. Polleit, 2007) claim that inherently damaging and ineffective central bank policies, including unsustainable expansion of bank credit through fractional reserve banking, are the predominant cause of most business cycles as they tend to set interest rates artificially low, i.e. "too low for too long" (Leijonhufvud, 2009), resulting in excessive credit creation, speculative "bubbles”, and artificially low savings. Under fiat monetary systems $s^{4}$, a central bank creates new money when it lends to member banks, and this money is multiplied many times over through the money creation process of the private banks. This new bank-created money enters the loan market and provides a lower rate of interest than that which would prevail if the money supply were more stable (Mises, 1912/1934; Rothbard, 1963/2000).

Although mainstream macroeconomists were almost completely surprised by the GFC, on the whole they were not led to re-appraise the explanatory power of the ABCT with respect to the U.S. housing bubble, the GFC and its aftermath. According to Salerno (2012) the mainstream criticism of canonical ABCT cen-

${ }^{4}$ Mises (1912/1934) wrote under the gold standard. 
ters on the fact "that the theory cannot explain the positive correlation of consumption and investment that occurs over the course of the business cycle. They [mainstream economists] allege that the theory predicts a slump in investment and capital goods' industries and a corresponding boom in consumption during recession. They therefore conclude that [canonical] ABCT is manifestly in conflict with the stylized facts of the business cycle" (Salerno, 2012: p. 3).

This conclusion derives according to Salerno (2012) from Haberler's (1937/1963) version of $\mathrm{ABCT}$ according to which the policy-induced boom is associated with an expansion of capital goods industries ("overinvestment") and a contraction of consumer goods industries ("forced saving"). Being completely symmetrical, the subsequent bust is characterized by a contraction of capital goods industries and an expansion of consumer goods industries. The composition of consumption and capital goods industries after the boom-bust cycle resembles pretty much the pre-cycle composition. It is for this reason that Haberler himself had problems accepting ABCT. Haberler (1937/1963: p. 71) commented that "it is a little difficult to understand ... why the transition to a more roundabout process of production should be associated with prosperity and the return to a less roundabout process a synonym for depression. Why should not the original inflationary expansion of investment cause as much dislocation in the production of consumers' goods as the subsequent rise in consumers' demand is said to cause in the production of investment goods?"

Krugman (1998), without attribution to Haberler (1937/1963), reiterates essentially the latter critique by arguing: "In the beginning, an investment boom gets out of hand... Whatever the reason, all that investment leads to the creation of too much capacity... Here's the problem: As a matter of simple arithmetic, total spending in the economy is necessarily equal to total income. So, if people decide to spend less on investment goods, doesn't that mean that they must be deciding to spend more on consumption goods - implying that an investment slump should always be accompanied by a corresponding consumption boom? And if so why should there be a rise in unemployment?"

Cowen (2008), applauding Krugman's (1998) criticism argues: "But I think the point is more effective in reverse. Why should the boom be a boom in the first place? The shift toward investment goods, and thus away from consumption goods' production, should mean falling real wages, not rising real wages. In other words, the Austrian theory doesn't generate the very high degree of comovement found in the data".

DeLong (2008) (falsely) characterizes canonical ABCT as an "overinvestment" theory along Haberler's (1937/1963) lines of thought commenting: "Something-irrational exuberance or fractional reserve banking or loose monetary policy - had pushed the market's tolerance for risk above 'sustainable' levels, the economy had responded by 'overinvesting' in capital, and no cure was possible that did not involve a recognition that capital had been overinvested and wasted and that the economy's capital stock needed to shrink." In similar critical vain 
Quiggin (2009) comments: "[T]he Austrian model implies that consumption should be negatively correlated with investment over the business cycle, whereas in fact the opposite is true. To the extent that booms are driven by mistaken beliefs that investments have become more profitable, they are typically characterized by high, not low, consumption."

Finally, Caplan (2008) ventures the most trenchant critique of ABCT as characterized by Haberler (1937/1963) when arguing: "If, as in the Austrian theory, initial consumption/investment preferences 're-assert themselves', why don't the consumption goods' industries enjoy a huge boom during depressions? After all, if the prices of the capital goods' factors are too high, are not the prices of the consumption goods' factors too low? Wage workers in capital goods' industries are unhappy when old time preferences re-assert themselves. But wage workers in consumer goods' industries should be overjoyed. The Austrian theory predicts a decline in employment in some sectors, but an increase in others; thus, it does nothing to explain why unemployment is high during the 'bust' and low during the 'boom'... [T] he theory does not predict an increase in employment during the boom, or a decrease during the bust. Moreover, it predicts an actual increase in current output during the bust. These are puzzling implications, to put it mildly, and they follow from the ABC[T]."

Salerno (2012: pp. 14-15) senses that all these mainstream critiques of ABCT are mistaken since they are based on a two-goods, two-factor general equilibrium model interpretation of ABCT which implies that too many resources allocated to the capital goods industries ('overinvestment') are associated with too few to the consumer goods sector. Overinvestment in a boom logically implies underconsumption, while underinvestment in a bust implies overconsumption. In order to make room for policy-induced distortions Salerno (2012: p. 14) claims that this model-interpretation of ABCT "differs not in the least from a two-commodity, two-country international trade model with increasing costs and incomplete specialization. In this model the imposition of a tariff, say, on wine will distort the relative price between wine and cloth, increasing the relative price of wine and stimulating the movement of resources from cloth to wine in the country importing wine. The relative price and flow of resources will move in the opposite direction in the wine-exporting country. If the tariff is then removed, the result will be counter-movement of resources out of each country's import-competing industry into its export sector." Substituting the tariff imposition for central bank interest rate manipulation, similar effects of sectoral relocations of resources as in the two-sector trade model will occur. "But ABCT was designed to explain the unique distortions created in the real economy and its production structure by an inflationary boom" Salerno (2012: p. 15).

\section{Extensions of Canonical ABCT to Explain GFC and Its Aftermath}

There is a consensus among several neo-Austrian researchers that without several modifications canonical ABCT cannot be used to explain the GFC and its 
aftermath appropriately (Young, 2012/2015; Salerno, 2012). One reason for this might be that Mises (1912/1934) developed his monetary theory of the business (trade) cycle under the international monetary system of the gold standard where the possibilities of the banking system to induce credit inflation were relatively few. Another argument goes that canonical ABCT must not be applied universally and mechanically to all business cycles. Young (2012/2015: p. 13) claims that in attempting to fit the GFC into the canon of ABCT, the neo-Austrians have failed to address two important aspects: “(1) The risk associated with the secondary mortgage market was externalized by the GSEs [= government sponsored enterprises] with the support of the US Treasury and Federal Reserve; (2) Housing, relative to other goods, is associated with a high degree of roundaboutness in consumption [italics in original]."

Young (2012/2015) starts his critique of attempts to fit GFC into canonical ABCT (as e.g. by Ebeling, 2008; Huerta de Soto, 2008, Boettke \& Luther, 2010) by observing that during the boom before the GFC mortgage rates were not actually low relative to rates in other financial markets which, however, they should have been, if it were in fact possible to apply ABCT mechanically to investments in housing markets. Young also questions whether housing production is particularly roundabout compared to other manufacturing industries. Unfortunately, there is no room here to go into the details of Young's (2012/ 2015) lucid exposition of GSEs' Freddie Mac (= Federal Home Mortgage Corporation) and Fannie Mae (= Federal National Mortgage Association) operations on U.S. mortgage markets and the explicit and implicit guarantees of U.S. federal government for GSE debt in the run-up to the GFC. It goes without saying that GSE activities involved considerable risk, since it nearly all stemmed from the one sector of the U.S. economy in which these enterprises operate: the housing/mortgage market. "While Fannie and Freddie's debt obligations were not explicitly backed by the federal government during the boom, market participants believed that they were implicitly backed." (Young, 2012/2015: p. 18) And as 2008 tells us, market participants' perceptions were right: the GSEs were taken into conservatorship and formally bailed out by the U.S. Treasury. Moreover, GSE debt was classified as U.S. government securities eligible for purchase by the Fed via its open market operations. It is thus no wonder that Fannie and Freddie enjoyed a 25 to 30 basis points advantage on their debt issues. Interest rates in the mortgage markets did not reflect the risk associated with the financial and underlying real assets. U.S. taxpayers had to take on the risk arising from policies encouraged by a series of legislative and administrative innovations from 1992 through 2004, policies that established credit targets for 'low-to moderate-income' and 'special affordable' households and 'underserved areas'. The Clinton administration requested that the HUD (=Department of Housing and Urban Development) direct GSE efforts towards these goals.

Second, the real assets underlying mortgages were only "exceptionally roun- 
dabout in terms of the services that they produced" (Young, 2012/2015: p. 20). The above-mentioned policies distorted the price signals in the housing market, thus inducing distortions in the intertemporal consumption structure. Since the distortions in construction and consumption are symmetric, misallocations serve not to offset but to amplify one another. (ibid) Low mortgage rates and rising home prices signaled to consumers that "(a) they could afford to finance a home over a long period of interest payments and/or (b) they could 'flip' the house in the near term" (Young, 2012/2015: p. 21). Regarding the latter case, Benitez-Silva et al. (2009) find that, from 2002 through 2006, homeowners overestimated their home's value by between 5 to 10 percent on average.

Young's (2012/2015) extension starts with Garrison's (2001) ABCT graphs ${ }^{5}$ (see Figure 1).

Figure 1 represents three co-ordinate planes: the bottom right plane has savings (denoted as S) and investment (denoted as D) on the abscissa and the real interest rate on the ordinate, the top right diagram has investment on the abscissa and consumption on the ordinate, while the left plane exhibits production time on the abscissa and the productivity value of roundabout processes on the ordinate. The graph on the top right features the macroeconomic production possibilities $(P P F)$ assuming exogenously given production resources and timestationary technology. The downward sloping curve represents various economically feasible combinations of consumption and investment. The bottom right diagram depicts the market for loanable funds. Savings rises with larger real interest rates, while investment declines with larger real interest rates. Absent policy intervention, individual savers supplying loanable funds $(S)$, and entrepreneurial investors demanding loanable funds $(D)$, determine the free-market equilibrium interest rate (=originary, or natural rate). That rate in the bottom right diagram determines the equilibrium bundle of consumption and investment goods consistent with macroeconomic production possibilities in the top right diagram. The diagram on the left is a Hayekian (1931) triangle providing the time structure of production. Investments determined in the top right diagram contribute

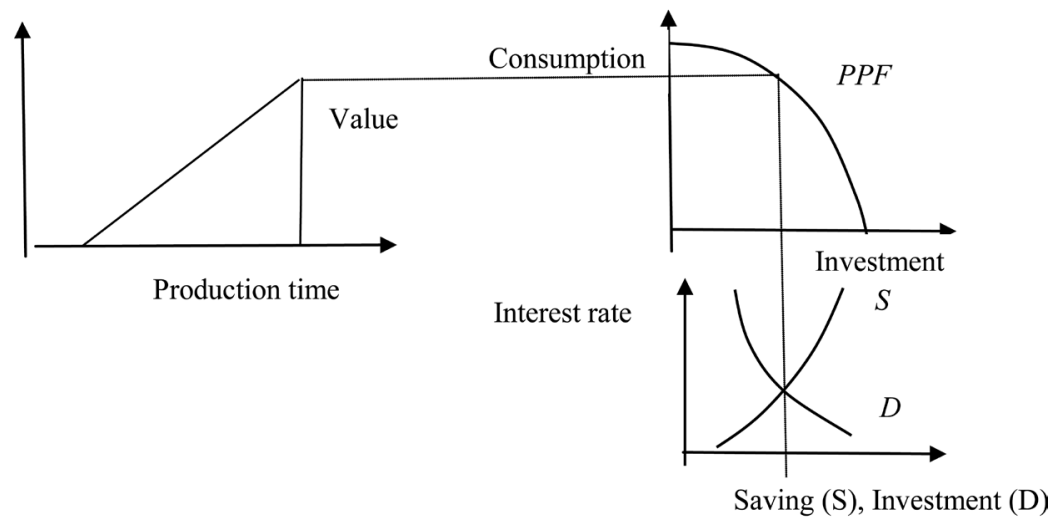

Figure 1. Garrison's (2001) ABCT graphs. Source: Young (2012/2015: p. 42). Present authors' presentation.

${ }^{5}$ The appendix presents a mathematical version of Garrison's (2001) model. 
to a complex capital structure one characteristic of which is the productivity (value) of roundaboutness measured by the vertical axis of the triangle in this diagram. The horizontal axis measures the time consumed during production. The hypotenuse of the triangle records goods thus far produced at each instant of time during the process, i.e. at each stage of production. "Holding the vertical right arm of the triangle in place, if the triangle expands leftward then the structure of production is lengthening; if it contracts rightward then the structure of production is shortening" (Young, 2012/2015: p. 22).

In order to provide more precision for the verbal presentation of canonical ABCT above, the effects of a (non-policy induced) decrease in the time preference of individuals are now considered in the diagrams of Garrison's version of canonical ABCT (see Figure 2). The decrease in time preferences induces individuals to save more as a portion of their income which is represented in the bottom right diagram of Figure 2 as rightward shift of the original savings curve $S$ depicted by the dotted $S$ curve. Supposing an unchanged demand for loanable funds, the increased supply of loanable funds initially results in a lower free market interest rate in the loanable-funds market in the bottom right diagram and with given production possibilities, a shift from consumption towards investment in the top right diagram of Figure 2.

The time structure of production expands in the Hayekian triangle of the left diagram of Figure 2 as the shift towards investment goods implies that a greater amount of resources is devoted to more roundabout production processes in order to cover future consumption needs. Investment in, and the production of, new capital goods expand the production possibilities (=capacity-enlarging effect of investment) depicted in the top right diagram of Figure 3.

The lengthened production structures associated with higher capital intensity lead to greater values of consumption and investment goods as is depicted by the outward shift of the production possibility curve and the hypotenuse of Hayek's triangle in the top right and left diagram, respectively, of Figure 3 below.

In line with Young (2012/2015) elements of risk-externalization and a time varying consumption structure are now introduced in Garrison's (2001) graphical

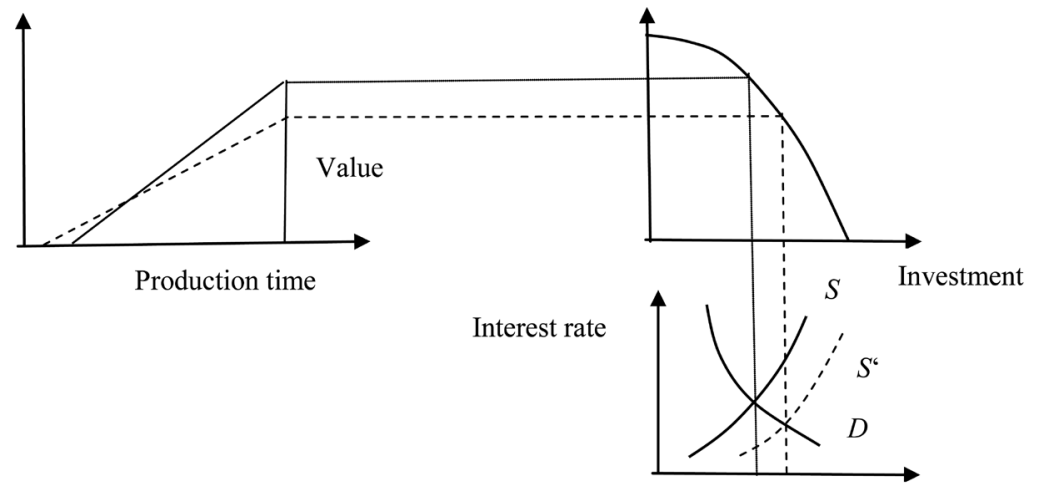

Saving $(S)$. Investment $(D)$

Figure 2. Effects of diminished individuals' time preference. Source: Young (2012/2015: p. 43). Present authors' presentation. 


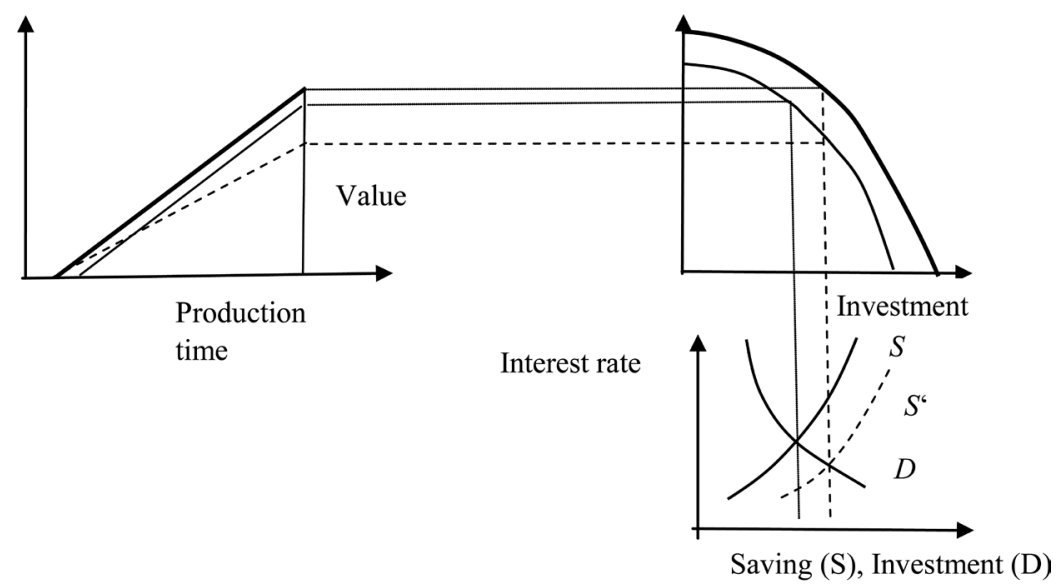

Figure 3. Productivity effects lengthen production structure. Source: Young (2012/2015: p. 43). Present authors' presentation.

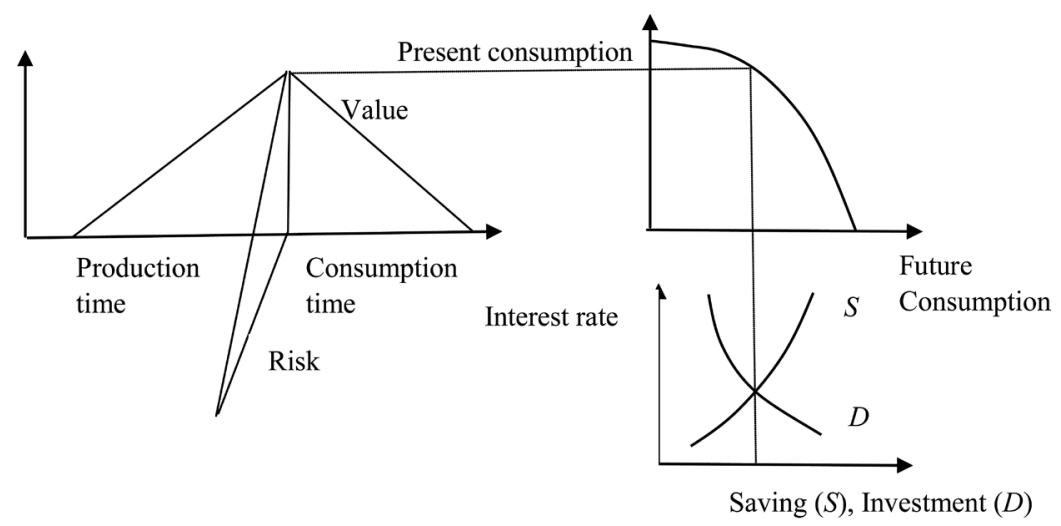

Figure 4. Time structure of consumption and risk structure in Garrison's (2001) canonical ABCT graphs. Source: Young (2012/2015: p. 44). Present authors' presentation.

exposition of the canonical ABCT (see Figure 4).

In Figure 4 the original Hayekian triangle representing production time is joined to another triangle pointing rightward and representing consumption time. The area of the right triangle representing the value of consumption goods produced indicates the length of time over which that total value is enjoyed. "The hypotenuse of the consumption triangle records the remaining value not yet enjoyed at each instant of consumption time" (Young, 2012/2015: p. 23). In line with the introduction of the consumption triangle the axes of the graph representing production possibilities are now relabeled from consumption and investment to, respectively, present consumption and future consumption. When resources are devoted towards more future consumption this can be accomplished either by foregoing present consumption through the accumulation of capital goods or foregoing present consumption by producing durable goods, the consumption services of which are used later rather than sooner.

Risk externalization provokes the introduction of an additional economic structure: the risk structure. Young (2012/2015: p. 25) claims that in addition to time (as in the canonical ABCT) risk is a further dimension of the complex cap- 
ital structure in a free market economy. In Figure 4, the axis projecting along a third dimension represents the risk involved in both the (time-related) production and consumption of value. "The vertical arm shared by all three triangles is now best interpreted as the expected value of consumption goods arising from production and to be enjoyed over time." (Young, 2012/2015: p. 25; Italics in original) The horizontal axis of the third triangle depicts risk. The triangle thus expands or contracts as more or less risk is being incurred during either the production or consumption process. As Young (2012/2015: p. 25) admits, in contrast to the former triangles, the interpretation of the hypotenuse and the area of the risk triangle is rather difficult.

Figure 5 depicts a policy-induced boom-bust cycle in canonical ABCT diagrams, save for the fact that the time structure of consumption is allowed to vary. The boom-bust episode represented is exactly as that depicted in Garrison's (2001) graphs but it is now possible to see how changes in the time structure of consumption amplify the policy-induced distortions. The expansion of money supply denoted by $\Delta M$ leads to an increase in the supply of loanable funds and-given an unchanged demand for loanable funds-to a fall in the market interest rate. Production shifts towards more future consumption in comparison to present consumption. Cheaper funds induce entrepreneurs to plan the completion of more roundabout production processes. Regarding consumers, lower interest rates incentivize consumers to plan on financing purchases of longer-lived consumption goods. In line with these plans, both the production and the consumption time expand in Figure 5.

"However, the sustainability of these more roundabout time structures - the completion of the production and consumption plans - depends on an increased amount of loanable funds being available not only today but also in the future at the depressed interest rate." (Young, 2012/2015: p. 27; Italics in original) However, individuals do not save more, and rates of time preference have not actually fallen.

As shown in Figure 6, facing a lower interest rate, individuals shift to more

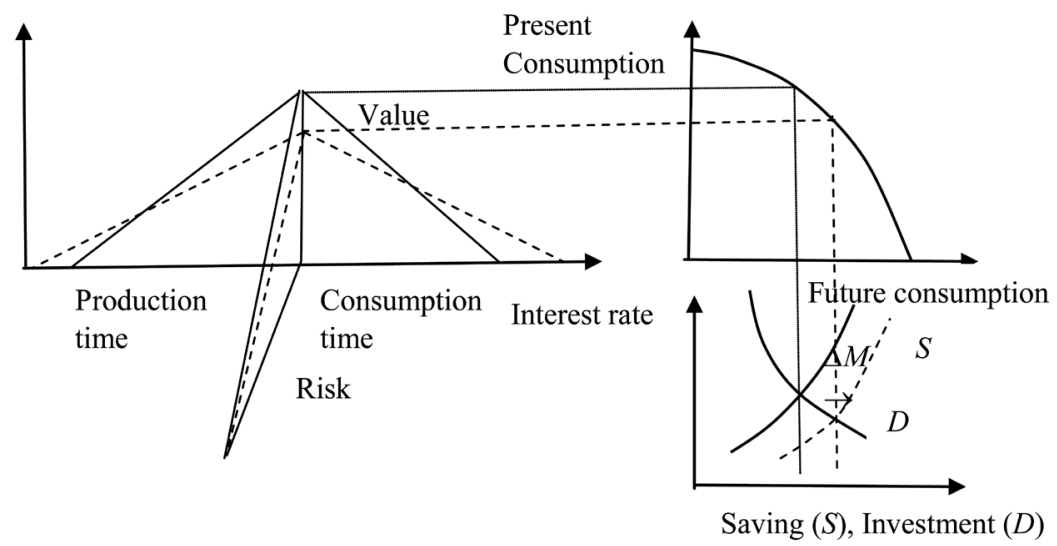

Figure 5. Policy-induced increase in the supply of loanable funds. Source: Young (2012/ 2015: p. 46). Present authors' presentation. 
present consumption relative to future consumption. Comparing the contracted time structure of the Hayekian triangles in Figure 6 to those in Figure 5, the discordance between production and consumption plans and the actual amount of voluntary saving become apparent. Planned investments within the production plans are revealed to be malinvestments. Regarding consumption plans, consumers base their plans on future savings that will never be realized.

At the time of bust, the shaded areas in Figure 6 embody inconsistencies between production and consumption plans which are distorted towards more roundabout structures and savings plans that are distorted towards being more present-oriented. "The inconsistencies mean that planned capital structures must be abandoned (e.g., half-built factories are left incomplete); also, that roundabout consumption plans must be aborted (e.g., mortgages are defaulted on; homes are foreclosed on)" (Young, 2012/2015: p. 28).

In line with Young (2012/2015: pp. 28-29; p. 46) the boom-bust cycle of the GFC is depicted in Figure 7 and in Figure 8. As Young claims, the channeling of financial funds into the housing market was effectuated through the secondary-market purchases of mortgages from GSEs. These were funded through an increased supply of savings (i.e., purchases of Fannie's and Freddie's debt) which was encouraged by externalizing the risk associated with mortgages. In Figure 7

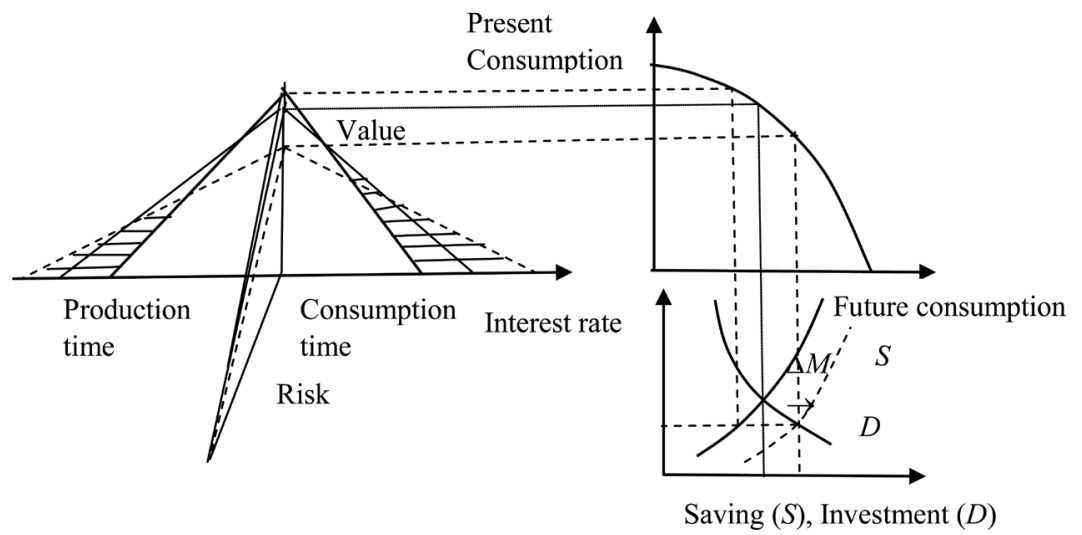

Figure 6. Distorted structures. Source: Young (2012/2015: p. 46). Present authors' presentation.

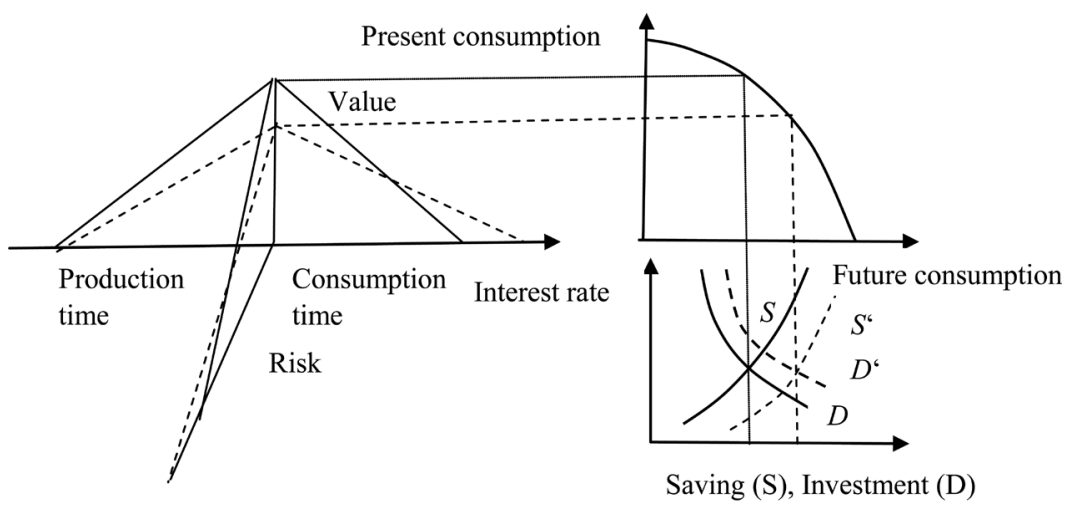

Figure 7. GFC's boom. Source: Young (2012/2015: p. 46). Present authors' presentation. 


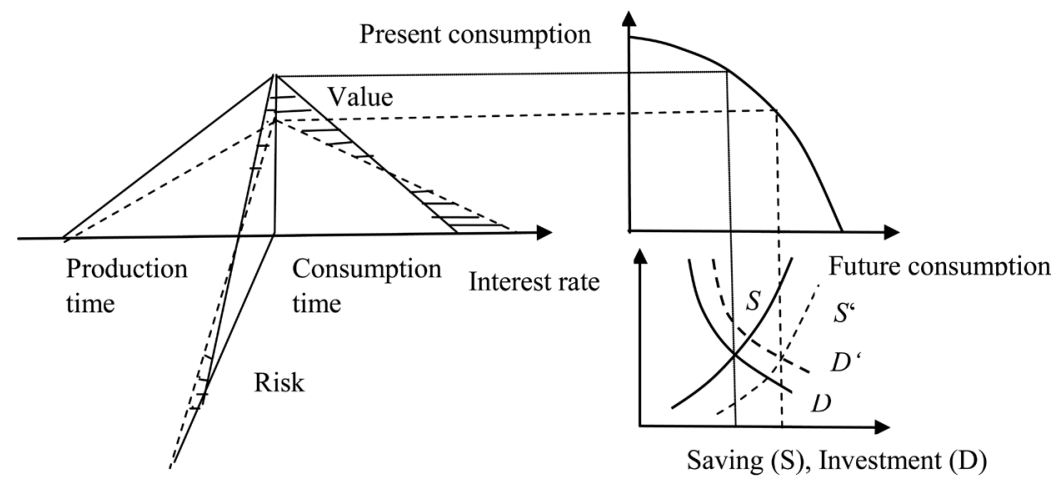

Figure 8. GFC's bust. Source: Young (2012/2015: p. 46). Present authors' presentation.

and Figure 8 the supply of the loanable funds curve shifts rightward from $S$ to $S$. “The GSEs' debt is implicitly guaranteed by taxpayers broadly and individuals who purchase it do not bear all of the risk associated with the activities of funding." (Young, 2012/2015: p. 29) But not only the supply curve shifts in the loanable funds market, the demand curve does too. The reason is that "by loosening their standards in terms of which mortgages they buy, the GSEs open borrowing opportunities to individuals who, by those previous standards, would have been deemed not creditworthy" (ibid).

As both supply and demand in the loanable funds market increase, the effect on the market equilibrium interest rate is ambiguous. As is well-known from the history of the Federal Reserve's monetary policy after the bust of the dot-com bubble, the federal funds rate and the whole ensemble of interest rates in financial markets was low, to some observers too low, for too long. On the other hand, as Young (2012/2015: p. 40) demonstrates, mortgage rates were not particularly low in comparison to other U.S. interest rates. The ambiguous effect on the interest rate in the loanable funds market thus makes the boom in the housing market more intelligible.

In Figure 8, the unsustainable economic distortions which became apparent during the GFC's bust are depicted as hatched areas in the three-dimensional Hayekian triangle. The right-hand triangle shows the inconsistences between the planned time structure of consumption and savings plans. Also hatched, are the discrepancies between the triangles drawn in the third dimension. "These discrepancies are between production and consumption plans initiated during the boom and alternative plans that are consistent with choices made assuming that the relevant risks are internalized" (Young, 2012/2015: pp. 29-30).

In order to put the original notion of ABCT, as described by Mises (1912/ 1934), Rothbard (1963/2000), and less emphatically by Hayek (1931/1935; 1933), into a more correct perspective, Salerno (2012: p. 5) further extends the analysis of canonical ABCT by looking at "the effects of the central bank's manipulation of interest rates, from entrepreneurial choice among the length of production processes, to household choice among intertemporal consumption patterns." Moreover, Salerno (2012) integrates the 'wealth' effect of credit inflation into 
canonical ABCT. Salerno shows how artificially inflated factor incomes and asset prices caused by the fiat-money fractional-reserve banking system facilitate "the falsification of households' assessment of their net worth and the distortion of their consumption/saving choices" (ibid). Thirdly, Salerno (2012: p. 6) links Hayek's (1935) "secondary deflation" to the "pervasive malaise and waning of 'animal spirits' among the mass of entrepreneurs that occurs when the recession reveals their cluster of miscalculation and errors and saps their confidence."

Salerno (2012: p. 7) starts his refinement of canonical ABCT by pointing out a rather startling fact concerning the GR 2008-2009, following the GFC 2007-2008, i.e. the exceptionally severe U.S. retail slump in addition to the collapse of the housing sector. For December 2008, year-over-year retail and food service sales declined in dollar values by 11.1 percent and from January through July 2009 these year-over-year declines fluctuated between 8.5 percent and 10.5 percent (Federal Reserve Bank of St. Louis, 2010). Real retail sales also declined over an exceptionally long period during the GR. While, in previous recessions, a monthly decline of 8 percent compared to a year earlier occurred only for three months, during the GR real retail sales on a year-over-year basis contracted by 8 percent and more for nine consecutive months. In fact, year-over-year retail sales declined for 23 consecutive months ending November 1, 2009 (ibid).

The severe U.S. retail slump in 2008 and 2009 represents a fundamental challenge to the validity of mainstream economists' interpretation of ABCT. Salerno (2012: pp. 15-24) is thus quite eager to elaborate on an interpretation of canonical ABCT which is consonant with the stylized facts of GFC and GR. First, he points out that $\mathrm{ABCT}$ is not an overinvestment theory of the business cycle but that 'overconsumption' and 'malinvestment' are the essential features of the policy-induced inflationary boom. In the views of Mises and Rothbard "the divergence between the loan and natural rates of interest caused by bank credit expansion systematically falsifies the monetary calculations of entrepreneurs choosing among investment projects of different durations and in different stages varying in temporal remoteness from consumers. But it also distorts the income and wealth calculations and therefore the consumption/saving choices of the recipients of wages, rents, profits and capital gains" (Salerno, 2012: p. 15). Artificially depressed loan rates incentivize business firms both to overestimate the present and future availability of investible resources and to malinvest in lengthening the structure of production, and thus mislead households into an overoptimistic appraisal of their real incomes and net worth, generating overconsumption and depressing savings.

Given expectations of future real incomes and consumer goods prices, depressed interest rates raise net wealth which encourages overconsumption (relative to the situation of non-distorted interest rates) provided it is financed by bank credit. "On the real side, the increase in the prices and profitability of consumer goods diverts factors from higher stages to consumer goods' industries, thereby restricting the supply of resources available to add to or even replace the 
stock of capital goods. This is what Austrian economists call "capital consumption", which is a pervasive feature of the boom. Far from being the essence of $\mathrm{ABCT}$, overinvestment is thus logically ruled out by it-the boom results in the production of fewer not more capital goods" (Salerno, 2012: p. 16).

Salerno refers to Mises (1949: pp. 546-547) who vividly describes the nature and implications of overconsumption: "It would be a serious blunder to neglect the fact that inflation also generates forces which tend toward capital consumption. One of its consequences is that it falsifies economic calculations and accounting. It produces the phenomenon of imaginary or apparent profits.... If the rise in the prices of stocks and real estate is considered as a gain, the illusion is no less manifest. What make people believe that inflation results in general prosperity are precisely such illusory gains. They feel lucky and become openhanded in spending and enjoying life. They embellish their homes, they build new mansions and patronize the entertainment businesses. ... It does not matter who these spenders are. They may be businessmen or stock jobbers. They may be wage earners..." (Italics in original).

Salerno refers also to Rothbard (1963/2000) who emphatically rejects the overinvestment interpretation of ABCT and states in Rothbard (1962/2004: p. 993): "Superficially, it seems that credit expansion greatly increases capital, for the new money enters the market as equivalent to new savings for lending. Since the new 'bank money' is apparently added to the supply of savings on the credit market, businesses can now borrow at a lower rate of interest; hence inflationary credit expansion seems to offer the ideal escape from time preference, as well as an inexhaustible fount of added capital. Actually, this effect is illusionary. On the contrary, inflation reduces saving and investment... It may even cause largescale capital consumption".

In contrast to Haberler's (1937/1963) interpretation of forced saving as the source of and impetus to overinvestment, Mises (1949: pp. 555-556) emphasizes that while at the start of a credit inflation, and to the extent that resources are released from consumer goods industries, forced saving will occur, the situation will inevitably be reversed the longer the boom goes on. As inflationary expectations become widespread the tendency toward overconsumption overwhelms the tendency to forced saving: "[W]ith the further progress of the expansionist movement the rise in the prices of consumers' goods will outstrip the rise in the prices of the producers' goods. The rises in wages and salaries and the additional gains of the capitalists, entrepreneurs, and farmers, although a great part of them is merely apparent, intensify the demand for consumer goods. .... As, apart from forced saving, the boom itself does not result in a restriction but rather in an increase in consumption, it does not procure more capital goods for new investment" (ibid).

Terminological differences regarding the notion of forced saving notwithstanding, Hayek (1935: pp. 320-321) describes the forces leading to overconsumption during a boom as follows: '[W]hether the prices of the consumers' 
goods will rise faster or slower, all other prices, and particularly the prices of the original factors of production will rise even faster. It is only a question of time when this general and progressive rise in prices becomes very rapid... Once this stage is reached, [a policy of credit expansion] will soon begin to defeat its own ends. While the mechanism of forced saving continues to operate, the general rise in prices will make it increasingly difficult, and finally practically impossible for entrepreneurs to maintain their capital intact. Paper profits will be computed and consumed, the failure to reproduce the existing capital will become quantitatively more and more important and will finally exceed the additions made by forced saving."

Obviously-although to a lesser extent than Mises-Hayek also emphasizes overconsumption during the later phases of the boom. It is also apt to point out that for Mises (1949) the interest rate is "much more important in its role as a discount factor than as an inducement to save." (Salerno, 2012: p. 20) Thus, Mises referred overconsumption back to the distortion of monetary calculation caused by credit expansion, which encourages entrepreneurs and consumers to overestimate their income and net worth. This calculational distortion generates both overconsumption and malinvestment. Assuming, as is realistic, that investing entrepreneurs first obtain newly created bank credit, they have the means and the incentive to start new more roundabout production projects at the artificially low interest rates. In addition, the demand and prices for higher stage goods needed to carry out these investments rise and concomitantly the capital values of firms producing these goods increase. "Resources are diverted into producing new mining and oil equipment, site planning and preparation for new hydroelectric plants, developing computer software for use in designing solar-powered aircraft and so on. At the same time, factors are being overused in supplying direct inputs to the manufacturers of finished consumer goods and in more intensively operating their facilities, as well as in constructing and manning additional warehouse and retail space. These malinvestments at both ends create a 'hole' in the middle stages of the structure of production, which is 'papered' over by profits and capital gains caused by the falsification of monetary calculation" (Salerno, 2012: p. 22).

As the boom continues, firms face an increasing scarcity of the resources needed to fully utilize the newly generated production facilities such that the lengthened structure of production cannot be 'completed'. The anticipated higher demand for the products of higher-stage investment goods does not materialize owing to the higher costs of complementary factors needed to transform them into the desired goods. Simultaneously, and as part of the same process, firms lower down in the structure of production that produce the inputs for production of finished consumer goods are also confronted with rising production costs causing them also to cut back on capacity.

From the neo-Austrian economic point of view "malinvestment and capital consumption cause the structure of production to disintegrate into pieces that 
cannot be fitted together again without a protracted recession-adjustment process. During this process both investment and consumption will decline causing unemployment to rise in both sectors. The recession will be further prolonged by the fact that the entrepreneurs, after experiencing massive losses and capital write downs, will temporarily lose confidence both in their ability to forecast future market conditions and in the reliability of monetary calculation. It is this loss of entrepreneurial confidence that is the crux of the so-called 'secondary deflation'." (Salerno, 2012: p. 23) Entrepreneurial demand for money and highly liquid assets will dramatically increase. Entrepreneurs will pass up potentially profitable investment opportunities which they would have seized upon under normal conditions. Salerno (ibid) rightly emphasizes the endogenous element of widespread entrepreneurial pessimism which brings about the drop in the general scale of prices with a larger fall of factor prices relative to product prices. This relative factor price decline implies a rise in the natural interest rate needed to restore entrepreneurial optimism. Or as Mises (1949: pp. 568-569) wrote more than seventy years ago: "[T]he depression brings about a cash-induced tendency toward an increase in the purchasing power of the monetary unit. Every firm is intent upon increasing its cash holdings, and these endeavors affect the ratio between the supply of money... and the demand for money ... for cash holding... The entrepreneurs enlarge their cash holding because they abstain from buying goods and hiring workers as long as the structure of prices and wages is not adjusted to the real state of the market data." Empirical data show that ten years after the GFC and GR, GDP per capita remained lower than in the boom period leading up to the GFC, a result of capital irretrievably sunk into unprofitable projects or consumed as a part of overoptimistically estimated future income, and that the impact of this remained even after malinvestments were liquidated and monetary calculation was re-established on a sound footing. The re-adjusted capital structure is shorter, while labor productivity, real wages and GDP per capita are lower. "The boom squanders through malinvestment scarce factors of production and reduces the stock available through overconsumption; its alleged blessings are paid for by impoverishment" (Mises, 1949: p. 573).

\section{Complementary Applications of ABCT on the Subprime Crisis and its Aftermath}

Young (2012/2015) and Salerno (2012) complementing Ravier and Lewin (2012), Fillieule (2013) and Cachanosky (2019) apply ABCT to an explanation of the so-called subprime crisis. Ravier and Lewin (2012: pp. 46-47) summarize their argument in the following eight statements: 1) Apart from the influence of sector-specific government policies, the subprime crisis or the 'housing bubble' can be traced back to the periodically rather loose monetary policy of the Fed, at least since 1980. 2) Focusing on the period after the bursting of the dot-com bubble in 2001 up to the end of 2004, the Fed expanded the money supply 
(measured by M2) at a rate of about 10 percent per year and slashed the federal funds rate from $6.25 \%$ at the start of 2001, to $1.75 \%$ at the end of 2001. Between 2002 and mid-2004 the federal funds rate remained at about 1\%. Compared to three monetary policy rules, i.e. Hayek's (1933) rule of maintaining constant nominal income, Friedman's (1960) rule of increasing base money slowly and at a constant rate, and Taylor's (1993) rule of mimicking past Fed interest policy, the federal funds rate was too low for too long. 3) This contradicts Greenspan's, and later, Bernanke's assertions that the subprime crisis was not rooted in Fed's interest policy but was associated with a global 'savings glut', caused by emerging countries like China and India whose excessively high savings rates (due, for example, to their lack of an adequate old-age security system) were channeled towards the U.S. financial system. 4) Contrary to popular claims that the deregulation of the banking system caused the crisis, for example, in the form of the repeal of the Glass-Steagal Act, Ravier and Lewin (2012: p. 46) assert that it was in fact excessive regulation of the U.S. banking system which channeled the newly created bank credit into real estate, thus distorting the capital structure of the U.S. economy. 5) After the boom in the housing sector between 2001 and 2004, enabled by the Fed's low interest rate policy, and its bowing to market pressure and fear of inflation, the Fed then raised the federal funds rate between 2004 and 2006 from 1\% to 5\%. As a consequence, this policy "produced the inevitable deflating of the bubble and the onset of crisis and recession, not only in the real-estate sector, but also in the banking sector which supported it during the boom" (Ravier \& Lewin, 2012: p. 47). 6). The bust of the housing bubble and the liquidity and solvency problems of financial institutions both inside and outside of the banking system ("shadow banks") had tremendous real consequences in that malinvestments in housing, in commercial residential structures, and in other long-term capital projects, could not simply be cancelled out or transformed into more adequate projects. The capital was simply lost. "The fundamental thesis of Hayek's theory of the business cycle was that monetary factors cause the cycle, but real phenomena constitute it." (Machlup, 1974: p. 504) Malinvestment means that the economy has declined, it has 'destroyed' or 'consumed' capital. Thus, many companies reduce production activities, lay off employees or are reluctant to engage new personnel. The U.S. GDP growth rate became dramatically negative, and the unemployment rate soared toward $10 \%$ in 2009 and remained there till 2011. The GR was in full swing despite the massive stimulus programs (more announced than realized) initiated by the U.S. congress and the U.S. federal government. 7) The Fed chairman, Bernanke, who had engaged in extensive study of the Fed's monetary policy after the 1929 stock market crash, justified the selective bailouts of troubled financial firms (those that were "too big to fail") and the massive liquidity injections into U.S. financial markets in terms of the need to avoid repeating the mistakes of the Fed between 1929 and 1933. Huerta de Soto (2009) questions this 'emergency strategy' by arguing that instead of a crisis that looks like a ' $\mathrm{V}$ ' (i.e. deep and short, as would be generated by pure market discipline), the Fed and U.S. treasury interventions led 
to an unnecessary prolongation of the GR. Ravier and Lewin (2012: p. 47), less radically, opt for open market operations in order to avoid moral hazard and political favoritism. 8) The U.S. Congress and the federal government followed an expansionary fiscal policy aiming at boosting employment and mitigating deflationary expectations. The Bush and Obama administrations and the state governments continued to accept huge fiscal deficits, even though the promised GDP and employment increases failed to appear until 2012.

Fillieule (2013), being a little bit more specific than Ravier and Lewin (2012), complements the latter's crisis description and ABCT analysis by adding some interesting details. Regarding U.S. expansionary monetary policy between 2001 and 2004, the Fed's Federal Open Market Committee (FOMC) justified the aggressive reduction of the federal funds rate between 2001 and 2002 "on the ground that there wasn't any inflationary pressure, and that without this policy a destructive spiral [after the bursting of the dot-com bubble] could have resulted from a loss of confidence by households and firms" (Fillieule, 2013: p. 106). Thus, credit expansion, the source of the subprime crisis according to ABCT, was then manufactured by the Fed in order to fight the recession following the bust of the dot-come bubble.

The direct consequences of the credit expansion induced by the lowered market interest rates were the artificial boom characterized by overconsumption and malinvestment. The lower interest rate enabled what would otherwise have been unprofitable investment projects to become profitable. Among the additional projects, most were capital-intensive, and thus quite responsive to the lowering of the interest rate. The structure of production is thus re-oriented towards longer term projects, as measured by the time it takes to produce the additional durable capital. "The structure of production is thus distorted in the sense that it suffers from a macroeconomic intertemporal disequilibrium-a 'malinvestment' in the Austrian terminology. Too many long-term projects are embarked upon, and the longer the artificial boom lasts, engineered by a greater and greater monetary creation, the more distorted the structure and the more acute the disequilibrium." (Fillieule, 2013: p. 107) For Fillieule (2013) the rapid economic growth of the U.S. economy from 2002 to mid-2006 (4.14\% in 2003, 3.35\% in $2004,3.05 \%$ in 2005) is in part an artificial boom generated by the expansionist monetary policy of the Fed. Pointing to the Case-Shiller home price index according to which U.S. house prices nearly doubled between 2000 and 2006, Fillieule (2013: pp. 108-109) diagnoses a deep malinvestment in the housing sector since a large part of the money created ex nihilo by the banking sector was spent on this sector, resulting in soaring housing demand and a skyrocketing of home prices. Specific factors, such as the support by Fannie Mae and Freddie Mac in subprime mortgages, the Community Reinvestment Act, and the development of adjustable-rate mortgages, all helped to channel a substantive part of the money created towards the housing sector. To counter Palmer's (2009) critique that houses do not represent long-term projects Huerta de Soto (2006: p. 348) argues 
that "durable consumer goods [such as houses] are economically comparable to capital goods throughout the period during which they are fit to render their services. Therefore, even in the case of consumer loans (to finance durable consumer goods), the greater influx of loans will tend to increase both the quantity and the quality of such goods". Moreover, Fillieule (2013: p. 123) explains that the distortion of the structure of production caused by the housing bubble is not a direct, but an indirect consequence of money creation in that the credit-fueled demand for factors of production in housing construction are pulled away from shorter processes and towards higher stages of production like construction materials, construction machinery and so on. In addition, the bubble was not limited to the housing and construction sector. A bubble was also noticeable in the stock exchange, as revealed by data on the S \& P 500 between 2003 and Q3 2006. To the extent that this nominal increase resulted from credit expansion, this is a sign of a lengthening of the structure of production and of malinvestment.

While U.S. stock prices increased rapidly between 2003 and Q2 2007, the U.S. consumer price index did not begin to display an inflationary tendency until the beginning of 2004. One reason for the delayed response in consumer prices is that credit expansion first affects the prices of factors of production and those of consumer goods somewhat later. Moreover, strong GDP growth also exerted a deflationary effect. Nevertheless, eventually, and after significant monetary creation, even consumer goods prices began to rise. This led the Board of Governors of the Fed to see the goal of price stability as being in danger. Thus, in June 2004, the FOMC started to reduce credit expansion and raised the federal funds rate for the first time in years. Following this, in order to fight consumer price inflation, the Fed raised the federal funds rate continually from $1.25 \%$ to $5 \%$ by mid-2006. From mid-2006 to mid-2007 the federal funds rate was held constant at the $5 \%$ level since by then the decrease in energy prices and the "slowdown" of house prices suggested a moderation of consumer price inflation was occurring. However, ABCT argues "that a pause or even a slowdown in the credit expansion leads to an adjustment crisis, because it prompts a rise in the rate of interest that in turn unveils the malinvestments plaguing the economic system" (Fillieule, 2013: p. 114). By mid-2006, the housing market was in severe disequilibrium because, before and also during the rise of the federal funds rate and other short term-interest rates, hugely excessive amounts of funding had been invested, particularly since "most of the home loans made during the boom period had an adjustable rate in order to benefit from the very low levels of short-term interest rates" (Fillieule, 2013: p. 115). The rise of the federal funds rate in a two-year period from $1.25 \%$ to $5 \%$ badly hurt those borrowers with an adjustable rate, and not surprisingly a significant number of them were no longer able to repay their debt. Housing demand sharply dropped, causing an unexpected reversal of the previous upward trend in house prices. The Case-Shiller home price index peaked in Q2 2006, the bankruptcies of mortgage dealers began in May 2006, and then multiplied in 2007. A year and a half after the housing bubble the stock 
market bubble burst. The Great Recession started in December 2007, real GDP decreased 0.7\% during Q1 2008, with the decline increasing successively from Q3 2008: e.g. $-2.7 \%$ in Q3 2008, $-5.4 \%$ in Q4 2008, $-6.4 \%$ in Q1 2009 and $-0.7 \%$ in Q2 2009. The unemployment rate exploded between the beginning of 2008 and mid-2009 from 5\% to 10\%. "In light of the sequence of events that has just been described, the 'subprime crisis' appears as a textbook illustration of the Austrian theory of the business cycle: a credit expansion engineered by the central bank greatly lowers the interest rates and generates a boom and accompanying malinvestments; a few years later, when price inflation begins to appear, the central bank decides to moderate the credit expansion, interest rates move up, the malinvestments are revealed, and the boom ends with a series of readjustment crises." (Fillieule, 2013: p. 116)

Cachanosky (2019: p. 89) notes that the 2008 crisis is one of the largest and most complex events in U.S. economic history. 2008 could not, and cannot be, predicted or explained with conventional macroeconomic models (Blanchard, 2014/2016; Blanchard, Dell'Ariccia, \& Mauro, 2010; Caballero, 2010; Keen, 2018; Stiglitz, 2011). In addition, the 2008 crisis better fits a scenario of nominal (monetary) shock than one of real shock. Two distinctive characteristics of the 2008 crisis need to be explained: how it came about in the first place, and why it happened specifically in the housing market. Any analysis of the crisis then needs to be separated into two different questions: why was it so severe, and why did it last so long?

Regarding crisis formation, Cachanosky (2019: p. 90) dismisses the often-heard assertion that the sharp fall in aggregate demand can be traced back to irrational behavior on the part of highly trained specialists faced with complex and new financial instruments. He claims that "empirical evidence suggests that the building of the housing bubble originated in a monetary policy deviation by major central banks rather than just on irrational exuberance." Cachanosky justifies this claim by stating that measured by five monetary policy rules besides the Taylor rule, the Fed's monetary policy between 2001 and 2004 was in fact expansionary. Using the Taylor rule, Ahrend et al. (2008: p. 101) find that those countries with the largest deviations from the Taylor rule also exhibited the largest housing bubbles. Compared to other consumer goods, housing is more interest rate sensitive since housing services are discounted over many years. Even former Fed chairman Bernanke (2013), who dismissed the assertion that the Fed's loose monetary policy created the housing bubble, conceded that one aim of the Fed's low interest policy was to boost the housing market. The fact that easy monetary policy was specifically addressed to the housing sector, can also be traced back to the incentives emanating from U.S. tax policy and federal regulations favoring homeownership. For example, instruments such as the Federal Housing Administration (FHA), founded in 1934, Fannie Mae founded in 1938 and Freddie Mac owned by the housing-industry until 1989, the Community Reinvestment Act (CRA) 1977, the homeownership incentive in the Tax Reform Act 1986, and the 
CRA reform 1995, were all part of government policy and regulations designed to favor house ownership. The participation of the two major GSEs (Fannie Mae and Freddie Mac) resulted in concentration instead of diversification of mortgage risk. In addition, the GSEs "played the role of an indirect and implicit (off the books) government bailout promise to mortgage lenders incentivizing an easy mortgage policy that increased the risk exposure to the housing market" (Cachanosky, 2019: p. 91). From the 1990s onwards the political pressures on commercial banks to loosen the conditions required to apply for a mortgage, for example, income and down payment requirements, steadily increased. Thus, between 2001 and 2006, the share of new subprime mortgages increased from $10 \%$ to $34 \%$. Moreover, due to the Fed's lowering of the federal funds rate, Adjustable-Rate Mortgages (ARM) became cheaper relative to fixed-rate mortgages, further increasing the overall risk of the mortgage market.

It is one thing to explain why the Fed's easy money flew into the housing market, it is quite another to explain why the subprime crisis was so deep. On the latter point, Cachanosky (2019: pp. 94-96) mentions several explanatory factors: 1) a fall in Nominal Gross Domestic Product (NGDP) in 2008, 2) the increase in regime uncertainty, decreasing the demand for credit in new business projects (Dixit \& Pyndick, 1994; Higgs, 2009), and 3) a cluster of misallocations of heterogeneous resources (physical capital as well as labor) during the 'too low for too long' interest rate policy of the Fed (the Cantillon effect). Hence, "[t]he severity of the subprime crisis can be explained by coupling the financial costs of mortgage delinquency with the Federal Reserve failure to stabilize NGDP... While prior to the Great Depression, a loose monetary policy channeled new credit to the stock exchange through financial brokers, prior to the 2008 crisis the new credit was channeled through mortgage issuers to the housing market. The expansionary policy that started in 2001 also incentivized the development of complex financial instruments that are hard to accurately price and whose risk is hard to assess. It is more likely that an excess of liquidity due to the easy monetary policy starting in 2001 contributed to the development of complex financial instruments and the housing bubble, rather than complex financial instruments being enough to fuel the housing bubble. The development of these complex financial institutions is another unintended consequence of the monetary policy that started in 2001 and its interaction with the housing market" (Cachanosky, 2019: p. 96). Several unexpected costs arose in the financial market after the bubble burst: Supposedly safe assets suddenly lost their market value, seriously affecting the balance sheets of large banking and insurance companies. The securitization of mortgages, while contributing to the diversification of risk globally, also served to mask the specific location of costs. This made it difficult for monetary authorities to detect the source of financial trouble. This became obvious during a series of rather arbitrary bailouts of troubled financial institutions (e.g. Bear Stearns, U.S. government's conservatorship of GSEs), all of which were considered too big to fail by the Fed and the U.S. Treasury. This 
served to stoke the expectations of other troubled companies (such as Lehman Brothers) with respect to their potential access to the available bailout funds, thus increasing the risk of moral hazard among financial institutions. "Rather than providing liquidity in general, the Federal Reserve, and the Treasury as well, were more inclined to provide focused assistance to those institutions in financial need that could endanger the whole financial market and target the specific financial assets in trouble." (Cachanosky, 2019: p. 97) The programs founded on this principle were the Trouble Asset Relief Program (TARP), run by the Treasury between October 2008 and December 2014, and the Fed's series of quantitative easing (QEI, QEII, and QEIII). Rather than buying and selling Treasury bonds in open market operations, under QE, the Fed also bought mortgage-backed securities (MBS). QEI started in late 2008 with a budget of $\$ 600$ billion to acquire MBS. QEII, started in late 2010 with a similar budget to that of QEI. QEIII allocated a $\$ 40$ billion (increased to $\$ 85$ billion) budget per month, with no maturity date and with no pre-stipulated budget limitation and ended in late 2014. Along with this rather unconventional policy framework, and with the objective of efficiently stimulating the economy, the Federal Reserve also carried out "Operation Twist". Under this policy, the Federal Reserve sold short-term bonds and bought long-term bonds. Operation Twist was intended to have a larger impact on the economic recovery than through short-term interest rates (which were already at their lower, zero bound). Finally, the excessive injection of liquidity into the financial markets by the Fed was sterilized by paying interest on the reserves that banks held with the Fed, thus putting a floor under the federal funds rate and reducing bank lending to firms and households in order to prevent price inflation. According to Hummel (2011), all these new monetary policy operations point towards a policy of monetary central planning. Such a policy suffers both from Hayek's pretense-of-knowledge syndrome (Caballero, 2010), and from a form of policy failure in that those institutions who were politically better connected tended to be the first to be bailed out by the Fed and the U.S. Treasury (Blau, 2017).

\section{Neo-Austrian Deflationist Critique of Fed's Post-Crisis Management}

Roughly speaking, three main policies were implemented in order to pull the U.S. economy out of the GFC and the GR: a bank bailout by the Treasury (TARP), emergency loans by the Fed to the banks, and unconventional monetary policy in the form of QE. The central aim of these policies was to boost aggregate demand and to avoid deflation at all costs, or in other words, to reflate the ailing U.S. economy after the burst of the subprime bubble. Following the bursting of the dot-com bubble, several neo-Austrian economists such as Hülsmann (2002), Bagus (2003), Salerno (2003) and Thornton (2003) had already argued against reflation and for deflation. Fillieule (2016) summarizes the arguments of these authors by stating, from a neo-Austrian point of view, why reflation is a 
bad idea while deflation is perceived as good.

The neo-Austrian arguments against reflation are in sharp contrast to the views of most other mainstream economists and can be attributed to ABCT's basic insight that a severe recession, such as the GR, originated in the credit expansion of the Fed between 2001 und 2004. Neo-Austrians believe that this distorted prices and interest rates, generated an artificial boom, both in housing and in the upstream and downstream sectors of the U.S. economy, caused widespread malinvestment within the U.S. structure of production, incited banks (under public sector 'nudging') to finance overly risky ventures, and brought about overconsumption by people misled by their possession of overpriced assets such as houses and stocks. In short, the recession was caused by the errors committed during the artificial boom induced by credit overexpansion and in order to return to a sustainable growth path such errors need to be corrected. From this point of view, it is highly questionable whether feeding malinvestments, i.e. by bailing out banks with troubled assets and implementing unconventional monetary policy à la QEI, QEII and QEIII, is conducive to achieving healthy growth. Or as Hayek (1933: p. 21) put it: "To combat the [recession] by a forced credit expansion is to attempt to cure the evil by the very means which brought it about."

In order to argue why deflation at the beginning of a severe recession is a good idea let us assume, in contrast to recent history, that the Fed and the U.S. government had done nothing to alleviate the bursting of the subprime bubble, i.e. that there were no bailouts, no emergency loans from the Fed, no open market operations, no quantitative easing (Fillieule, 2016L pp. 104-105). "With the onset of the recession, households hoard more in order to cope with the higher level of uncertainty, and banks restrict credit in order to replenish their reserves. Some banks go bankrupt, and the whole pyramid of credit money they have created in the past is wiped out. It follows that aggregate spending and prices significantly fall." (Fillieule, 2016: p. 105) The rapid decrease of aggregate demand and prices lets profits shrink, especially if output prices decrease quicker than factor prices, and profit expectations dramatically deteriorate. "However, even in this very dramatic phase of the process, plagued by a very high dose of uncertainty, proper anticipation is possible. Many entrepreneurs may be petrified for a few days, but paralysis is not good for business. They will rather quickly play their proper role again and actively reallocate capital towards the firms and branches that will earn profit-or at least curtail losses-during and after the deflationary phase." (ibid) Most importantly, without any measures to reflate the economy, the phase of deep deflation will be relatively short-lived. Moreover, deflation will indeed be briefer since falling prices trigger the anticipation of further falling prices which induces money hoarding and a freeze in purchases until the prices have dropped so far that the rising purchasing power of money (real balance effect) offsets the income losses due to unemployment, whereby spending recovers and production and employment become profitable again. Thus, prices reach "rock bottom" 
(Hülsmann, 2002) rather quickly. It is not conceivable that the central bank's money, and the commercial banks' demand and savings deposits, completely disappear. Thus, spending cannot totally disappear either. Households continue to consume and firms continue to buy input factors, albeit at a significantly reduced scale compared to that found in an artificial boom.

In contrast to the highly aggregative reasoning of traditional Keynesianism, neo-Austrian authors point out that "the deflationary spiral does not affect all the economic agents in the same way" (Fillieule, 2016: p. 105). Just as the inflationary process of an artificial boom brings about a process of redistribution, so too does deflation induce a redistribution of wealth among citizens. These wealth effects vary, depending on the party concerned, i.e. on whether one is a household, indebted firm, equity holder, or bank (Hülsmann, 2011).

Regarding households, deflation means that loans, particularly mortgage debt, become more expensive or impossible to repay. In the latter case the house will be seized through foreclosure and the household will have to pay back the difference between the mortgage and the now reduced nominal value of the house. Since there will be a cluster of households in the same difficult situation house supply will dramatically increase and there will be a tendency for house prices to fall quicker than the prices of other goods. As a consequence, indebted households will suffer from more or less dramatic monetary losses. The more the households are indebted, the more severe the deflation will be.

Firms in debt will become unable to repay their loans and their owners will lose their firms to creditors. However, this change in ownership, as such, does not destroy the productive capacities of these firms. These capacities may still be used by new creditors and entrepreneurs to run operations profitably. Similarly, while firms financed through equity capital are bound to lose a part of their book value, their owners and managers can still continue operations, albeit at a (probably) much reduced level: "The deflation as such is no reason why they should lose their assets or have to sell them. In both cases, the firms will of course have to carry out the adjustments required by the deflationary phase and its aftermath-putting to the test the entrepreneurial skill of whoever owns them" (Fillieule, 2016: p. 106).

On average, banks are hit hard by deflation. In the worst case many banks go bankrupt or are taken over by their creditors, i.e. by customers who have deposited their money with, or lent their money to, the banks. While bank customers lose money, they remain entitled to some share in the banks' real estate assets.

When the deflationary process has come to an end and wealth (property) is redistributed along the lines outlined so far-presupposing a well-functioning system of courts and arbitration-this does not yet mean that the misallocations that originally caused the crisis have been corrected (Mises, 1949). The production of capital goods last for months and years. In most cases it takes several years to adapt the capital structure to the new pattern of savings and consumer demand, especially to correct for the induced artificial undercapitalization in the 
production sectors. The traces of both severe malinvestment and acute overconsumption will (must) therefore be erased through deflationary reallocations. Deflation affects the economic agents differently and the effect is stronger in sectors where it is most needed, i.e. in those sectors that were distorted by malinvestment and overconsumption. In contrast to the mainstream view, deflation accelerates the inevitable adjustment process of the structure of production towards healthy growth through "non-anemic" capital accumulation, and through technological innovation more in line with uninflated savings.

Although there are several mainstream economists who use, more or less explicitly, neo-Austrian arguments (e.g. Borio \& Disyatat, 2011; Caballero, 2010; Calvo, 2013; Hume \& Sentence, 2009; Meltzer, 2009; Schwartz, 2009; Taylor, 2009) in explaining the GFC and the GR, no mainstream economist has been willing to accept the deflationary laissez faire scenario described above. Here, the profession clearly follows Bernanke's (2002) perspective concerning the negative consequences of a widespread decline in consumer prices caused by a collapse of aggregate demand. Such a perspective depicts a sharp increase in real interest rates. E.g. an expected $10 \%$ decline in the price level transforms a $2 \%$ nominal interest rate into a $13 \%$ real interest rate. Such a high interest rate then deters firms and households from borrowing and leads borrowers to reduce capital investment, purchases of new homes and other types of spending, thus worsening the economic downturn. The reason for this is that while prices are falling debtors must repay the principal in currency of increasing real value. Debtors are thus often unable to pay back their loans, leading to an accumulation of non-performing loans for banks and endangering the stability of the banking system.

In contrast to the negative consequences of a surge in real interest rates as described by Bernanke (2002), Fillieule (2016: p. 108) argues that the spike in the real rate is not all that detrimental because the price decline during the deflationary process takes place much more rapidly than the rise in prices occurring during the previous period of credit inflation. Moreover, the sharp increase of the real interest rate and the widespread uncertainty among economic agents who hoard money, both serve to accelerate the price deflation until prices hit 'rock bottom'. When the downward price spiral is over, the deflationary component of real interest rates vanishes. Real interest rates settle at levels higher than those prevailing during the artificial boom, and given that savings have now adjusted, are still appropriate to attract sufficient capital investment and innovations.

That deflation hurts borrowers, in that they must repay more in real value than originally contracted for, is undisputable. Hence, borrowers may have to sell or forsake their collateral because their earnings no longer suffice to repay principal and interest. Moreover, the collateral will not yield enough money to cover the repayment since post-deflation prices are lower than the nominal value of the loan. Nonetheless, although many people will lose their (inflated) wealth there are other individuals who gain real wealth by becoming owners of houses, 
factories and machines which cannot be destroyed through price deflation. Thus, while there is a redistribution of wealth, there is not necessarily a reduction in national wealth.

Finally, the potential instability of the banking sector as a result of non-performing loans is only a problem when the size achieved by the banking sector during the credit boom is already at an optimum for economic development. Given that such an optimum is unlikely, as the Austrians argue, then bankruptcies of over-leveraged banks are in fact quite healthy. Bank managers and owners then become more attentive to risk, and this serves to stabilize the whole system, probably better than well-intentioned (but often ineffective or distortionary) macroprudential measures imposed by bank regulators.

\section{Questioning Deflationist Laissez Faire and Recent Neo-Austrian Responses}

The deflationist approach to the aftermath of the GFC presented in the previous section raises the question of why the Fed's zero interest rates and unconventional monetary policy has not led to a new downturn. According to neo-Austrian thinking, the Fed's unprecedented expansionary monetary policy has created an artificial boom. Where is the crash? Thus, it is not surprising that financial analysts and investment advisers continue to doubt neo-Austrian explanations of the crisis, and refuse to believe that deflationist policy advice can be of any help in understanding the main mechanisms leading to the GFC and the weak recovery after the GR. Moreover, while several neo-Austrian authors were successful in predicting the subprime bubble and the subsequent GFC, the Austrian-inspired predictions of several U.S. economists with Republican leanings, as expressed in a famous open letter to the Fed chairman, Bernanke, in 2010, have so far failed to materialize. In that letter, the signatories warned that the Fed's implementation of QEI would lead to runaway inflation and currency debasement. "As we know now, exactly the opposite happened. Inflation remained very low and the dollar remained strong. This wasn't a surprise to anyone but the Austrians, so there is an obvious need to explain these awkward facts away." (Seeking Alpha, 2019). In contrast to neo-Austrians, the predictions of those economists who are more Keynes-oriented have proven correct. The latter stated that QE policies would not be inflationary "as long as interest rates are close to zero, as the economy experiences a liquidity trap where the demand for money becomes highly elastic so that the public holds any amount of money that is created." (ibid) Under such circumstances, monetary policy is incapable of driving market interest rates below the alleged natural rate (the neo-Austrian bogeyman) and hence a zero-interest rate and unconventional monetary policy do not generate an unsustainable boom.

Apart from its bad forecasts over the past decade, ABCT is also said to suffer from several conceptual problems. First, the natural rate is not observable. This implies that it is impossible to diagnose unequivocally whether policy-induced 
market interest rates really are below the natural rate. With respect to the historical decline of real interest rates in advanced economies since 1980, mainstream economists claim that several factors have led to a decline in the natural rate, e.g. the global savings glut, population aging, dematerialization, digitization, etc. all of which preceded the introduction of the recent unconventional monetary policy.

Second, supposing that Fed's expansionary monetary policy since the GR drove market interest rates below the natural rate, why is Hayek's investment boom not visible in the data? The absence of such a boom is no surprise to non-Austrian economists since they believe, in contrast to proponents of the ABCT, that business investment is not interest sensitive. Such interest-rate sensitivity would only be better for ABCT if it could then be used to explain the allocation of wealth between financial and real investment.

Third, there is the conundrum that according to the Austrian economic world view while entrepreneurial economic agents can correctly interpret the price (interest rate) signals from unhampered markets, they are simultaneously fooled by such price signals, leading to malinvest and overconsumption, when central banks drive the market interest rates below the natural rate.

How do neo-Austrian authors and Austrian-inspired economists respond to such reasoned critiques of canonical and extended $\mathrm{ABCT}$ ?

The response given by Polleit (2019) is illuminating in this respect: "Since central banks have established a rather firm grip on market interest rates, the chances are that the ongoing boom will continue-and it may well continue for much longer than most market observers expect at the current juncture." The objective of the central bank is, from Polleit's (2019) neo-Austrian point of view, to prevent the return of the 'manipulated' market interest rates to the natural rate. As we know from canonical $\mathrm{ABCT}$, it is the return of market interest rates to their natural level that turns the boom into bust. Central banks' grip on the market interest rates concerns both the short-term and the longer-term interest rates. By fixing targets for the federal funds rate the Fed governs short-term interest rates in the inter-banking funding market and exerts a rather strong influence on credit rates across all maturities. In addition, central banks also influence long-term interest rates, and this more directly, by purchasing long-term bonds, thus determining the latter's price and yield. "The credit market 'government securities' can be expected to already be under full control of monetary policy makers, and it is just a technicality for any central bank to extend its purchases if needed to bank and corporate debentures and mortgage debt." (ibid) This might be a reason why the market for government bonds, already enormously enlarged by skyrocketing government deficits, has not yet crashed (this is probably also due to the elevated savings of the deleveraging private sector).

By keeping market interest at historically very low levels the inherent correction mechanism of unhampered credit markets namely the rise of market interest rates towards their natural level is made inoperative and this explains why the boom can be kept going and the inevitable bust postponed. "Basically, all 
major central banks around the world have taken recourse to policies controlling market interest rates, and quite effectively so as the economic expansion-fueled by malinvestment and overconsumption-in the last decade testifies" (Polleit, 2019: p. 2).

Thus, the question arises as to how long the U.S. economy can flourish with artificially low interest rates? Polleit's (2019) answer is: Until the market interest rates hit zero. At the point of zero interest rates, savings and roundabout production processes then end, capital consumption kicks in and the intertemporal division of labor collapses. Currently, U.S. market interest rates have not yet reached this game changing level. As long as there is still room to push market interest rates down, for mortgage and corporate credit costs, in particular, there still appears to be room for further decline, and the "party" can be kept going. Concomitantly, the policy-induced depression of market interest rates pushes asset prices to unprecedentedly high levels since expected profits are discounted at low interest rates which increases their present values and thus stock prices. Moreover, low interest rates reduce firms' capital costs, translating into higher current profits which also contribute to higher stock prices. Although low market interest rates are by no means the only factor explaining high stock prices, they are highly significant from the neo-Austrian point of view.

As already pointed out by Mises (1949), as long as the boom continues people rejoice given the steadily increasing "paper" wealth fueled by buoyant asset returns. However, with meager returns to saving, investment in roundabout methods of production will not take place, and businessmen cannot specialize in making tools and intermediate products more efficiently so that consumer goods can be produced more cheaply or in better quality. The lack of yield on investment in roundabout methods incites people to buy stocks, land, and real estate, thus pushing up asset prices. "As the purchase price of these assets rises relative to their 'intrinsic' value, future investment returns diminish and in the extreme case converge towards central bank's zero interest rate" (Polleit, 2019: p. 3). In contrast to suggestions that the natural interest which equates savings and investment, in the absence of (monetary) policy interventions, approaches zero, Polleit (2019) reiterates a basic Austrian insight: due to the time preference of the acting man or woman-being a consumer or a producer-the "originary" (Mises, 1949) or natural (Wicksell, 1898/1936) interest rate always remains larger than zero. Polleit (ibid) also reminds the reader of another basic Austrian insight: The longer the boom keeps going, the bigger the distortions in the economy and financial markets become. While ABCT does not enable us to come up with a reliable forecast with respect to when the boom will turn into bust, it is still able to assert that "market interest manipulation through central banks damages on a grand scale and will end badly-something that may only be prevented by a helping hand from above" (Polleit, 2019: p. 6).

In a more recent commentary Polleit (2020) cites Bob Prince, co-chief investment officer at Bridgewater Associates, who claimed that the boom-and bust-cycle in the last decades may have come to an end. Recent economic data appears to 
be quite supportive concerning the continuation of the present (already rather lengthy) US boom. There appears to be a fundamental clash between present data and the neo-Austrian insight that a boom brought about by artificially low market interest rates must inevitably turn into bust. Polleit (2020) is thus quite eager to "outline the 'special conditions' which must be taken into account if the ABCT is applied to real-world developments." The market-distorting control of short- and long-term interest by central banks puts a "safety net" under the financial markets. In the eyes of investors central bankers are believed to be responsible for financial stability, and thus the latter will always step in vigorously to fight an impending crisis. This encourages moral hazard since it implies that some part of the additional risk entailed when taking on additional investment projects may be disregarded. However, this "safety net", provided courtesy of central bankers, is in reality a stealthy form of intervention in capital markets, leading to higher prices and lower yields than would be the case in unhampered markets. The central bank intervention is thus tantamount to market manipulation. It induces consumers and producers to make wrong decisions and prolongs the boom beyond the period that would exist under free capital market conditions.

Recently, central bankers have focused on policies "that push down selected types of markets' yields, in particular those in the funding markets for government debt, mortgage debt, and bank debt" (Polleit, 2020: p. 3; italics in original). As a consequence of minimal or even negative yields in bond markets, investors shift their financial resources towards stocks and real estate raising the prices of such assets and curtailing their future yields. In this way, all asset returns are dragged down towards the zero yields of the assets manipulated by the central bank. However, once all market interest rates hit zero, the boom turns to bust. "Credit markets shut down, borrowers can no longer roll over their maturing debt, and no investor is willing to lend new funds. To prevent credit defaults and the collapse of the debt pyramid, central bankers would presumably step in as 'lenders of last resort', refinancing basically all kinds of borrowers in need. An outright inflation policy would begin. Nevertheless, capital consumption and economic regression would set in. People's living standards would nosedive; many would be thrown into outright misery." (ibid)

Contrary to optimistic claims that central banks have achieved an end to the boom-bust cycle, according to neo-Austrian insights, they have merely succeeded in prolonging a boom which will surely end, at the latest, when all market interest rates are zero. At this point the positive time preference of economic agents ensures that the intertemporal division of labor through roundabout capital accumulation collapses. Thus, the Keynesian presumption ${ }^{6}$ that capitalist boom-bust cycles can be prevented in that central banks and governments may steadily create quasi-booms is unmasked as being mere wishful thinking, often

\footnotetext{
"It is not an exaggeration to claim that a Keynesian solution to a bubble having burst is to create a new bubble. ... Thus, in uncovering the anatomy of the current [2008] crisis, we see the underpinning themes of previous crises where Keynesian emergency measures were taken as a response." (Boettke \& Palagashvili, 2016: p. 243).
} 
entailing harmful consequences for the average man and woman.

Mayer and Schnabl (2019) come to a similar conclusion by contrasting Keynesian, neoclassical and Austrian explanations for low interest rates and sluggish growth. While the Keynes-Hansen-inspired authors (Bernanke, 2005; Summers 2014) and neoclassical authors such as Gordon (2012), attribute falling real interest rates to factors such as a global savings glut driven by population aging, debt deleveraging after the subprime crisis, declining demand for fixed capital investment due to digitalization, and a declining marginal efficiency of capital, Austrian-inspired Mayer and Schnabl (2019: p. 3) attribute the gradual decline of interest rates in advanced countries to "asymmetric monetary policies, i.e. strong interest cuts during crises, which were not followed by respective interest increases during the post-crisis recoveries". In order to substantiate this claim Mayer and Schnabl (2019) first point out that traditional Keynesian and neoclassical macro-models lack a banking sector and thus cannot capture the capital market implications of asymmetric monetary policy. In contrast, their Austrian-inspired model contains a banking sector which either finances the fixed capital produced or the financial investments. The well-known Keynesian macro identity $S=I$ is extended as follows:

$$
P^{\mathrm{nf}} \cdot I^{\mathrm{nf}}+P^{\mathrm{f}} \cdot I^{\mathrm{f}}=S^{\mathrm{n}}+\Delta C .
$$

$P^{\mathrm{nf}}$ denotes the price for real non-financial investment $I^{\mathrm{If}}$, and $P^{f}$ the price for real financial investment $f$, such as stocks and real estate. $S^{\text {n }}$ depicts planned nominal savings and $\Delta C$ is credit creation of banks. The authors assume that real non-financial investment, real financial investment, and bank credit creation, are negatively associated with the central bank-managed interest rate, while nominal savings are positively related to this interest rate. Moreover, Mayer and Schnabl (2019: p. 11) state that both the prices of real non-financial, and real financial investment, are positively related to their respective investment volumes. Thus, if the central bank lowers short-term (and by unconventional monetary policy also long-term) market interest rates, non-financial and financial investment and bank credit increase, while planned savings decline. Thus, a positive gap between aggregate investment (=demand for loanable funds) and nominal planned savings occurs, i.e. an artificial boom is set up. During the boom non-financial real investment and/or financial investment rise (depending on the policy incentives for more non-financial or more financial assets). "As deposit rates are low, consumers have an incentive to withdraw deposits from banks and buy stocks of enterprises and banks, whose profits are increasing during the upswing. If stock prices are expected to rise further, speculation may set in (Hayek, 1931/1935), with the valuation of stocks becoming delinked from their fundamentals. A credit boom evolves, with prices of financial and non-financial investment rising." (ibid) With an ongoing boom wages rise, forcing firms to raise their selling prices, which in turn induces the central bank to increase the bank rate. With higher market interest rates non-financial and financial investments with relatively low returns will then be abandoned. As the central bank 
keeps the interest rate high after the peak of the business cycle, the commercial banks tighten credit. Non-financial and financial investments are cancelled, and their prices fall. Since heterogeneous capital goods cannot be transformed easily into other goods more akin to the demanders' distorted preferences, unemployment will rise.

Since central banks change the targets for their bank rates asymmetrically-slashing market interest rates when recession commences but refraining from increasing rates when bubbles in stocks and real estate arise (due to not having enough information to spot and prick bubbles) - market interest rates decline towards zero. However, with declining market interest rates the average productivity of investment is negatively affected. While financial and non-financial investments with rather low productivity are realized during the boom, these rather inefficient investment projects will not be abandoned during recession. Thus, average investment productivity decreases and with it the dynamics of GDP growth.

After Mayer and Schnabl (2019) examine the theoretical arguments for Keynesian and neoclassical explanations of the savings glut and of secular stagnation, they then take a look at the relevant empirical data. Citing the results of the econometric study of Demary and Voigtländer (2018) they find that total factor productivity growth (secular stagnation) has no influence on real interest rates, and-in contrast to the savings glut hypothesis-that the old-age dependency ratio has a negative influence on real interest rates. In Japan, with its rapidly aging population, Latsos (2019) finds that the main determinant of the decline in Japanese saving rates has been the fall in market interest rates induced by Japan's central bank. Firms' savings rates (not those of households) have increased in some advanced countries such as Japan and Germany due to low capital costs and windfall profits as a result of exchange-rate depreciations. In contrast to Gordon (2012), OECD data show that the marginal productivity of capital-empirically measured by the ratio of the absolute change of real output year over year to real investment of the current year-has not changed since 1990 in the U.S.A., Japan and Germany, while it has decreased in China since 2008. On the other hand, the decline of market interest rates has boosted real financial investment with financial markets expanding through new asset classes (asset-backed securities) and has propped up financial asset prices relative to consumer prices. Using Gordon's (1959) growth model of equity valuation, Mayer and Schnabl (2019) show that with declining market interest rates the priceearnings ratio increases. This is shown using the U.S. S \& P 500 Shiller cyclically adjusted price earnings-ratio before 2007 and after 2009 (see Figure 8 in Mayer \& Schnabl, 2019: p. 20).

As is well-known from the dynamics of the primary deficit to GDP ratio (see e.g. Farmer \& Schelnast, 2013: p. 85), if the (real) interest on (government) debt is driven below the GDP growth rate, increasing (government) debt levels remain sustainable. This is also true for business debt which implies that firms 
can raise the return on equity through financial leverage, rather than through non-financial investment which would be more conducive to productivity growth. According to the Dupont analysis (see Gropelli \& Nikbakht, 2000: pp. 444-445) the return on equity can be raised by increasing the profit margin, capital productivity, and/or financial leverage. Since capital productivity remained stationary over time (with the exception of China) and the increase in profit margins in a roughly competitive situation is limited, the return on equity could only be raised through an increase in financial leverage, i.e. through more debt relative to equity capital. As Figure 8 in Mayer and Schnabl (2019: p. 21) shows, firms in the U.S.A., China and in Germany, have raised their indebtedness significantly since the beginning of the 2000s, especially in the aftermath of GFC. Owing to the prevailing skepticism regarding future economic development, the cheap additional funds have been used for mergers and acquisitions and equity repurchases instead of for investment in riskier non-financial capital. Investment in financial instead of in production capital, together with the continuation of relatively unprofitable firms in business tend to act as a drag on productivity growth. This was shown by McKinnon (1973) and Shaw (1973) for developing countries in the 1950s and 1960s, where government-directed real investment at financially repressed interest rates depressed growth. More recently, in a similar vein, Acharya et al. (2019) have attributed the lower productivity growth in the Euro area to the zero-interest rate and unconventional monetary policies of the European Central Bank. The policy-induced distortions of funds diminished the incentives of banks to remove bad loans from their balance sheets and served to squeeze the margins of traditional banking since both the credit margin (= credit rates minus deposit rates) and the transformation margin (long-term minus short-term interest rates) shrank. At some point interest rate cuts have a negative effect on credit growth, investment and output, since the positive effect of low interest rates on bank assets is overcompensated by the negative effect on banks' profits (Brunnermeier \& Kolby, 2019). The decline in bank asset values forces banks to restrict lending.

As indicated by the drop in average capital productivity in Japan in 1990-91, in the U.S.A. and in the Euro area in 2007-08, and by its relatively slow recovery since then, economic troubles in the financial sector seem to spill over into the real economy. As a consequence, real GDP growth has been lagging behind its long-term trend. "The upshot is that output growth has declined, while increasingly loose monetary policies have prevented or even reduced unemployment by preserving distorted economic structures. Even more, in many countries, such as Japan and Germany, the number of employed increased as real incomes declined, and more people entered the labor market. Therefore, the increasingly expansionary monetary policies of the large central banks have come along with declining labor productivity" (Mayer \& Schnabl, 2019: p. 26). This rather sorry state of affairs reminds us of Kornai's (1986) diagnose of "soft budget constraints" in the former communist countries in central and eastern Europe. Since 
unemployment was incompatible with communist ideology state banks were forced to provide unconditional credit to over-manned, poorly managed companies. The losses of the state-owned banks were covered by the printing press of the central banks. Low productivity and meager real wage growth hampered the rise of people's living standards. "From this perspective the persistently loose monetary policies are like 'soft budget constraints', which have become a major impediment to productivity growth" (Mayer \& Schnabl, 2019: p. 27).

\section{Conclusion}

The renewed interest in ABCT in the immediate aftermath of the GFC and the GR has been due to both the explanatory deficiencies of mainstream macroeconomics and to the ability of some neo-Austrian economists to correctly warn about the U.S. housing bubble and the disastrous consequences of its bursting. The success of neo-Austrians in evaluating the pre-GFC U.S. boom clearly serves to stimulate analysis of the basic tenets of the Mises-Hayek, or canonical, ABCT. In contrast to the Keynes-Hansen oriented explanations of crises, (global savings glut, secular stagnation, etc.), canonical $\mathrm{ABCT}$ attributes boom-bust cycles (such as the GFC and its pre-Corona aftermath) to the extra-loose monetary policies of central banks and to the credit supply of fractional reserve banks. Such well-intentioned intervention in financial markets depresses market interest rates below the "originary" (Mises) or "natural" (Wicksell) rates and incentivizes entrepreneurs and consumers to start more roundabout production processes and to increase consumption due to an artificial increase in wealth. However, since households had not really increased savings, the resources needed to produce high and low-stage goods are not available. Production processes cannot be completed, what appeared to be profitable investments turn out to be malinvestments, and overconsumption turns into a consumption slump. Keynesian-like policy suggests that the lack in private aggregate demand can be offset by adopting a more accommodative monetary policy and an increase in government deficit spending. This is rejected by proponents of the ABCT since they believe that the origin of the crisis is not the aggregate demand failure following the bust, but the inappropriate credit expansion during the boom. Moreover, the policy-orchestrated support of financially struggling firms and households merely serves to conserve an inefficient structure of production and thus hampers the path to recovery and healthy economic growth. Furthermore, even if the deflationary process after the bursting of the bubble is allowed to erase malinvestment in higher and lower-stage production sectors, the traces of the credit-induced boom will remain, i.e. there will still be lower GDP per capita at higher interest rates than before the credit expansion.

While some neo-Austrian authors use canonical ABCT to explain the GFC and its aftermath, Young (2012/2015) extends canonical ABCT to come to grips with the impact of the supposedly over-expansive monetary policy of the U.S. Fed and the channeling of credit into the U.S. housing sector. If canonical ABCT 
were true, expansionary monetary policy should have depressed mortgage rates below the returns of other financial assets. However, this, was not in fact the case. In addition, since housing production is not particularly roundabout, the housing boom cannot be explained by canonical ABCT. In order to address these problems within an extended ABCT model, Young (2012/2015) adds two dimensions to the Hayekian triangle in Garrison's (2001) ABCT graphs: consumption-time, and risk. The externalization of mortgage risk through the implicit bailout guarantees of the U.S. Treasury, with GSE (Fannie Mae and Freddie Mac) securitization raising the supply of loanable funds and the policy-induced loosening of lending standards of commercial banks raising the demands for loanable funds, is then used to explain the negligible effect of over-expansive monetary policy on mortgage rates. By adding a consumption-time and a risk triangle, the policy-induced financing of more long-lived consumption goods (such as houses) and the increased riskiness of these investments and associated malinvestments in production and non-realization of consumption plans, can thus be depicted.

Salerno (2012) extended canonical ABCT by including the effect of artificially inflated wealth in household consumption decisions in order to counter mainstream economists' criticisms of $\mathrm{ABCT}$ and to be able to explain, through the extended ABCT, the 2008-2009 U.S. retail slump. Through the inclusion of a wealth effect, and in contrast to mainstream critics, Salerno (2012) is able to $e^{-}$ plain the positive correlation between consumption and investment during the boom and the bust. This extension is particularly important in that it makes the severe retail slump, occurring during the GR in the U.S.A., much more intelligible. Moreover, Salerno (2012) links Hayek's (1935) "secondary deflation" to the widespread malaise and over-pessimistic expectations occurring among entrepreneurs when a recession reveals the extent of their miscalculation and error, and saps investor confidence. Contrary to mainstream opinion the implied entrepreneurial procrastination with respect to investment and production accelerates the fall in factor prices and the rise in the natural rate of interest. This serves to overcome the pervasive demoralization often existing among entrepreneurs and capitalists in times of a slump.

Without making an explicit extension of canonical ABCT, neo-Austrian authors Ravier and Lewin (2012), Fillieule (2013), and more recently Cachanosky (2019), provide useful complementary explanations for the U.S. subprime crisis and its aftermath. Among many quantitative empirical facts describing the housing boom and the subsequent bust the above authors underline that in spite of the repeal of the Glass-Steagal Act in 1998, it was the excessive regulation of the U.S. banking system which allowed for credit money to be channeled into real estate, thus distorting the U.S. production structure. Moreover, the existing malinvestments in housing, in commercial and residential structures, and in other long-term capital projects, could not simply be removed or transformed into profitable projects-the capital was simply lost. As Hayek long ago asserted: 
Monetary factors cause the business cycle, but real phenomena constitute it.

Among other things, Fillieule (2013) reports on an interesting statement of the Federal Open Market Committee justifying aggressive reduction in the target federal funds rate between 2001 and 2004. It seems the FOMC believed that there were no grounds for expecting inflationary pressure, and that due to the loss of confidence by households and firms after the bursting of the dot-com bubble, without federal funds rate reductions a destructive downward spiral of prices, production and employment would set in. Policy-induced lower market interest rates make more capital-intensive projects profitable since they are particularly interest-rate sensitive. Too many long-term projects are embarked upon, and the longer the artificial boom lasts, engineered by ever greater monetary creation, the more distorted the production structure becomes and the more acute the disequilibrium. For Fillieule (2013), the near doubling of U.S. house prices between 2000 and 2006 is a clear signal of deep malinvestment in the housing sector fueled by numerous US laws and directives designed to stimulate homeownership. Excessive money creation also distorts the structure of production indirectly by pulling factors of production from lower stages to higher stages of production, thus increasing claims on products needed for house construction.

Cachanosky (2019) distinguishes between factors underlying the formation of the crisis, and factors resulting in the subprime crisis becoming so deep. Addressing the first point, Cachanosky (2019) tests (and verifies) the claim that the Fed's monetary policy between 2001 and 2004 was extremely loose, by using as measuring rod six monetary policy rules. He also points out that relative to other consumer durables housing is more interest rate sensitive since the interest rate is used to discount housing services over many years. Even Fed chairman Bernanke conceded that the aim of accommodative Fed policy was to boost the housing market. In combination with housing and tax policies favoring homeownership, the concentration of mortgage risk in GSEs, plus the implicit promise of government bailouts should things go wrong, the share of subprime mortgages rose from 10\% to 34\% between 2001 and 2006. Cachanosky (2019) attributes the depth of the crisis to the fall of NGDP in 2008, the increase in regime uncertainty, and to a cluster of misallocations of heterogeneous resources. Prior to the Great Depression abundant credit money was channeled through financial brokers to the stock market. In contrast, prior to the $G R$, new credit was directed through mortgage issuers to the housing market. In addition, excessive liquidity through loose monetary policy also triggered the development of complex financial instruments which were hard to price or value accurately. Rather than buying and selling Treasury bonds in open market operations, the Fed (and Treasury) granted assistance to specific agents in the financial market which were deemed too big to fail. Taken together, the near-zero interest rates, quantitative easing policies, Operation Twist and the Fed's paying of interest on bank reserves, can be seen as a form of monetary central planning, exhibiting a strong 'pretense-of-knowledge' syndrome and allowing plenty of room for policy 
failure in the sense that political connections can govern bailout decisions.

This rather abstract critical assessment of U.S. monetary (fiscal) policy is substantiated by Fillieule's (2016) deflationist critique of the Fed's post-crisis management, which was intended to reflate the U.S. economy and to avoid deflation at all costs. Several neo-Austrian authors, after the bursting of the dot-com bubble, had already argued against reflation and for deflation. They simply took Hayek's (1933) argument to heart that to cure the recession by a forced credit expansion is to attempt to cure the evil by the very means which brought it about. Fillieule (2016) then elaborates on what the consequences might have been if neither the Fed nor the U.S. Treasury had in fact intervened after the bursting of the subprime bubble. Fillieule posits that due to the high level of uncertainty and the numerous bankruptcies of banks and firms, the hoarding of money and other goods by households and firms would still take place. Nonetheless, after a short phase of paralysis he believes that due to the rapid decline of sales prices entrepreneurs would reallocate resources from unprofitable sectors to newly profitable ones. In the absence of state intervention, deflation would be deep but short-lived because the expectation of further falling prices induces a halt in purchases, thus accelerating market price decline until the real value of money balances increases and spending recovers despite the income losses arising from unemployment. However, since the deflationary spiral does not affect all economic agents in the same way, a redistribution of wealth among households, firms and banks would take place. Even after the deflationary redistribution has come to an end, it takes two or three years until the capital structure is adjusted towards the new intertemporal equilibrium. Fortunately, the recession resembles a ' $\mathrm{V}$ ' assuming no attempt is made to support unprofitable firms, but not a 'W' with recovery taking 8 - 10 years (Reinhart \& Rogoff, 2009). In contrast to Bernanke's (2002) contra-deflation arguments involving a rapid rise in real interest rates, the inability of debtors to repay their loans and the danger of a banking collapse, Fillieule (2016) argues that the spike in real interest rates would be relatively short, debtors' defaults induce wealth redistribution but not a reduction of aggregate wealth, and that the bankruptcy of overleveraged financial actors during the boom is healthy.

While the neo-Austrian (Shostak, 2003; Thornton, 2003) warnings concerning the existence of the U.S. subprime bubble tend to vindicate ABCT, the state-orchestrated recovery of the U.S. economy since the GR, and the boom in the US economy since late 2016, raise several questions pertaining to the relevance of the neo-Austrian explanation of the crisis, especially regarding its deflationist approach in the pre-Corona aftermath of the GFC. Thus, neo-Austrians Polleit $(2019,2020)$ and Mayer and Schnabl (2019) felt obliged to develop new lines of defense for ABCT. Polleit (2019) argues that the U.S. recovery since 2010 and the more recent boom since 2016 are the result of policies by the Fed and the other large central banks which are designed to keep a firm grip on both short-term and long-term market interest rates. The boom will turn into bust 
when all market interest rates are driven towards zero. However, since the rate of return on various financial assets is yet larger than zero there is still room for the present boom to continue.

Mayer and Schnabl (2019) compare Keynesian, neoclassical and (neo-) Austrian theories about low (even negative) real interest rates and sluggish growth. They extend the well-known macro-identity of savings equals investment by subdividing investment into non-financial and financial investment and extending aggregate savings to capture the credit creation of banks. Non-financial and financial investment, as well as bank credit creation, depends negatively on the central bank rate, whereby savings depend positively on the central bank rate. If the central bank lowers market interest rates below the natural rate, a positive gap between aggregate investment and planned savings occurs: the boom sets in, financial and non-financial investment rise, and given the relatively low interest rates earned on deposits households withdraw their deposits from banks and buy stocks of enterprises and banks in the expectation of rising prices and returns as a result of increasing asset values. With the ongoing boom, wages and other factor prices begin to rise and firms raise sales prices in order to cover their rising costs. Rising consumer prices energize central banks to raise their bank rates now making those financial and non-financial investments exhibiting a low return unprofitable. Non-financial investment projects cannot be finished, and financial investments are cancelled. The prices of these assets fall, whereby banks then tighten credit. Unemployment rises since heterogeneous capital cannot be adjusted to the distortions in demand without incurring losses. Mayer and Schnabl (2019) attribute the empirically observable decline in interest rates since the 1980 s to an asymmetric monetary policy, i.e. to a slashing of interest rates when recession raises its head, and a refrainment from raising bank rates when bubbles in equity stock and real estate arise. Citing the results of recent empirical studies several neo-Austrians feel entitled to reject Keynesian and neoclassical explanations of low interest rates. On the other hand, the cheap funds created by the massive liquidity injections of central banks have found their way to corporations and have been used for mergers and acquisitions and buy-backs of outstanding equity stock instead of being invested in risky non-financial capital projects. The policy-induced distortion of funds diminishes the incentives of banks to remove non-performing loans from their balance sheets and squeezes the margins of traditional banking. Economic problems in the financial sector spill over to the real economy, as can be seen by the prevailing low average capital productivity and GDP growth figures which remain below the long-term trend. While output growth declined, successively looser monetary policy has managed to raise employment, acting as a drag on labor productivity. Persistently loose monetary policies resemble Kornai's (1986) "soft budget constraints" in former communist states where inefficient full employment and low productivity growth prevented a rise in living standards.

Mainstream economists consider the U.S. recovery since the GR, and the 
boom in the U.S. economy since 2016 as proof of the validity of the Fed's reflation policy and of the inappropriateness of (neo-) Austrian deflationist policy advice. Neo-Austrians, in contrast, interpret the success of the Fed's reflation policy and the hitherto absence of a decline in the current policy-induced boom, as a step on the 'road to serfdom' in the sense that firms, households and states are now subject to the whim of central bankers who can implement soft budget constraints allowing for inefficiently low unemployment at the expense of low productivity growth, and for stagnating or even declining living standards, especially for the younger population cohorts (Schnabl, 2017). Much on this fundamental disagreement on the appropriate policy stance towards the pre-Corona aftermath of the GFC "hinges on the answer to the underlying question of whether the actions and interventions of Big Players in mixed economies are stabilizing or destabilizing" (Van den Hauwe, 2016: p. 55). Mainstream economists believe that such interventions, if conducted appropriately, can be stabilizing. (Neo-) Austrian authors, in contrast, hold that they are destabilizing since time and again they generate boom and bust cycles. Even with the benefit of hindsight it remains difficult to judge who is correct. However, one can safely maintain that the mainstream's neglect of neo-Austrian views on the GFC and its pre-Corona aftermath does nothing to enhance economists' understanding of severe financial crises. Fortunately, there are voices from both sides of the camp who are willing to consider promising areas of cross-fertilization concerning the GFC and its pre-Corona aftermath (St. Oppers, 2002; Cachanosky \& Salter, 2017).

Based on the conclusion thus far the main innovation and contribution to research of the paper consists of the insight that a serious and unbiased study of neo-Austrian analyses of financial crises and its aftermath by mainstream macroeconomists is both thought-provoking and enhancing the analytical power of macroeconomic research.

However, the limitations of the present overview of neo-Austrian views of the GFC and its pre-Corona aftermath are also obvious. Due to the nature of an overview, it scratched only the surfaces of both the neo-Austrian crisis theory and its mainstream critics. In order to arrive at a more informed judgement about the stabilizing or destabilizing effects of massive interventions of Big Players like central banks and federal treacheries into mixed economies the notion of real savings in an "augmented" loanable funds theory (Hartwick, 2018) with banks as financial intermediaries should be thoroughly investigated. However, this must remain the task of future research.

\section{Conflicts of Interest}

The authors declare no conflicts of interest regarding the publication of this paper.

\section{References}

Acharya, V., Eisert, T., Eufinger, C., \& Hirsch, C. (2019). Whatever It Takes: The Real Effects of Unconventional Monetary Policy. The Review of Financial Studies, 32, 3366-3411. https://doi.org/10.1093/rfs/hhz005 
Ahrend, R., Cournède, B., \& Price, R. (2008). Monetary Policy, Market Excesses and Financial Turmoil. Working Paper No. 597, OECD Economics Department. https://doi.org/10.2139/ssrn.1302789

Bagus, P. (2003). When Austrians Become Interventionists. The Quarterly Journal of Austrian Economics, 6, 19-35. https://doi.org/10.1007/s12113-003-1002-6

Benitez-Silva, H., Eren, S., Heiland, F., \& Jiméez-Martin, S. (2009). How Well Do Individuals Predict the Selling Prices of Their Homes? Levy Economics Institute Working Paper No. 571. https://doi.org/10.2139/ssrn.1107165

Bernanke, B. S. (2002). Deflation: Making Sure It Doesn't Happen Here. Paper presented at the National Economists' Club, Washington DC.

Bernanke, B. S. (2005). The Global Saving Glut and the U.S. Current Account Deficit. Sandridge Lecture, Richmond, VA: Virginia Association of Economists.

Bernanke, B. S. (2013). The Federal Reserve and the Financial Crisis. Princeton and Oxford: Princeton University Press. https://doi.org/10.1515/9781400847167

Blanchard, O. (2009). The Crisis: Basic Mechanisms, and Appropriate Policies. IMF Working Paper WP/09/80. https://doi.org/10.5089/9781451872279.001

Blanchard, O. (2014). Where Danger Lurks. Finance \& Development, 51, 28-31.

Blanchard, O. (2016). Do DSGE Models Have a Future? Policy Brief No. 16-11, Peterson Institute for International Economics.

Blanchard, O., Dell'Ariccia, G., \& Mauro, P. (2010). Rethinking Macroeconomic Policy. Journal of Money, Credit and Banking, 42, 199-215.

https://doi.org/10.1111/j.1538-4616.2010.00334.x

Blau, B. M. (2017). Lobbying, Political Connections and Emergency Lending by the Federal Reserve. Public Choice, 172, 333-358. https://doi.org/10.1007/s11127-017-0446-8

Boettke, P. J., \& Luther, W. J. (2010). The Ordinary Economics of an Extraordinary Crisis. In S. Kates (Ed.), Macroeconomic Theory and its Failings. Cheltenham: Edward Elgar Publishing. http://ssrn.com/abstract $=1529570$ https://doi.org/10.4337/9781849803397.00008

Boettke, P. J., \& Palagashvili, L. (2016). The Comparative Political Economy of the Crisis. In: Horwitz, S. (Ed.), Studies in Austrian Macroeconomics. Advances in Austrian Economics (Vol. 20, pp. 235-264). Bingley: Emerald Group Publishing Limited. https://doi.org/10.1108/S1529-213420160000020011

Borio, C., \& Disyatat, P. (2011). Global Imbalances and the Financial Crisis: Link or No Link? BIS Working Paper No. 346. https://doi.org/10.2139/ssrn.1859410

Brunnermeier, M., \& Kolby, Y. (2019). The Reversal Interest Rate. IMES Discussion Paper 19-E-06. https://doi.org/10.3386/w25406

Caballero, R. J. (2010). Macroeconomics after the Crisis. Crisis: Time to Deal with the Pretense-of-Knowledge Syndrome. Journal of Economic Perspectives, 24, 85-102. https://doi.org/10.1257/jep.24.4.85

Cachanosky, N. (2019). Monetary Equilibrium and Nominal Income Targeting, In Routledge International Studies in Money and Banking. Abingdon-on-Thames: Routledge.

Cachanosky, N., \& Lewin, P. (2016a). Financial Foundations of Austrian Business Cycle Theory. In: Horwitz, S. (Ed.), Studies in Austrian Macroeconomics. Advances in Austrian Economics (Vol. 20, pp. 15-44). Bingley: Emerald Group Publishing Limited. https://doi.org/10.1108/S1529-213420160000020002

Cachanosky, N., \& Padilla, A. (2016b). A Mathematical Version of Garrison's Model. The Quarterly Journal of Austrian Economics, 19, 225-247. 
Cachanosky, N., \& Salter, A. W. (2017). The View from Vienna: An Analysis of the Renewed Interest in the Mises-Hayek Theory of the Business Cycle. The Review of Austrian Economics, 30, 169-192. https://doi.org/10.1007/s11138-016-0340-5

Calvo, G. A. (2013). Puzzling over the Anatomy of Crises: Liquidity and the Veil of Finance. IMES Discussion Paper Series 13-E-09, Institute for Monetary and Economic Studies.

Caplan, B. (2008). What's Wrong with Austrian Business Cycle Theory? EconLog. http://econlog.econlib.org/archives/2008/01/whats wrong wit $6 . \mathrm{html} /$

Cowen, T. (2008). Paul Krugman on Austrian Trade Cycle Theory. Marginal Revolution. https://marginalrevolution.com/marginalrevolution/2008/10/paul-krugman-on.html

DeLong, B. (2008). I Accept Larry White's Correction... Cato Unbound. https://www.cato-unbound.org/2008/12/11/j-bradford-delong/i-accept-larry-whites-co rrection

Demary, M., \& Voigtländer, M. (2018). Reasons for the Declining Real Interest Rates. IWF Report 47/18.

Dixit, A. K., \& Pyndick, R. S. (1994). Irreversible Investment. Princeton, NJ: Princeton University Press.

Ebeling, R. M. (2008). The Current Economic Crisis and the Austrian Theory of the Business Cycle. The Freeman: Ideas on Liberty.

https://fee.org/media/5292/0806freeman ebeling.pdf

Evans, A. J., Cachanosky, N., \& Thorpe, R. (2019). The Upper Point in the Austrian Business Cycle Theory. https://ssrn.com/abstract $=3145284$ https://doi.org/10.2139/ssrn.3145284

Farmer, K., \& Schelnast, M. (2013). Growth and International Trade. An Introduction to the Overlapping Generations Approach. Berlin: Springer.

https://doi.org/10.1007/978-3-642-33669-0

Federal Reserve Bank of St. Louis (2010). National Economic Trends. http://research.stlouisfed.org/publication/net/

Fillieule, R. (2013). The Explanation of the Subprime Crisis According to the Austrian School: A Defense and Illustration. Journal des Économistes et des Études Humaines, 19, 101-136. https://doi.org/10.1515/jeeh-2012-0006

Fillieule, R. (2016). The U.S. Monetary Policies against the Great Recession of 2008: A Critique from the Deflationist Viewpoint of the Austrian School. Journal des Économistes et des Études Humaines, 22, 99-111. https://doi.org/10.1515/jeeh-2016-0007

Friedman, M. (1960). A Program for Monetary Stability. New York: Fordham University Press.

Garrison, R. W. (2001). Time and Money. The Macroeconomics of Capital Structure. New York: Routledge. https://doi.org/10.4324/9780203208083

Gordon, M. (1959). Dividends, Earnings, and Stock Prices. The Review of Economics and Statistics, 41, 99-105. https://doi.org/10.2307/1927792

Gordon, R. (2012). Is U.S. Economic Growth Over? Faltering Innovation Confronts the Six Headwinds. NBER Working Paper No. 18315. https://doi.org/10.3386/w18315

Gropelli, A., \& Nikbakht, E. (2000). Finance. New York: Hauppauge.

Haberler, G. (1937/1963). Prosperity and Depression. New York: League of Nations.

Hartwick, C. (2018). Against Savings. A Suggested Exposition of the Markets for Money and Credit. https://doi.org/10.2139/ssrn.3021115

Hayek, F. A. (1931/1935). Prices and Production (2nd ed.). New York: Augustus M. Kelley. 
Hayek, F. A. (1933). Monetary Theory and the Trade Cycle. New York: Augustus M. Kelley.

Hayek, F. A. (1944). The Road to Serfdom. Chicago, IL: The University of Chicago Press.

Hendrickson, J. R. (2019/2020). Review of "The Skyscraper Curse and How Austrian Economists Predicted Every Major Economic Crisis of the Last Century". The Independent Review, 24, 448-451.

Higgs, R. (2009). Regime Uncertainty. The Independent Review, 11, 561-590.

Horwitz, S. (2012). What the Austrian Business Cycle Theory Can and Cannot Explain. Coordination Problem.

https://www.coordinationproblem.org/2012/02/what-the-austrian-business-cycle-theor y-can-and-cannot-explain.html

Horwitz, S. (Ed.) (2016). Studies in Austrian Macroeconomics. In Advances in Austrian Economics (Vol. 20). Bingley, UK: Emerald Group Publishing Limited. https://doi.org/10.1108/S1529-2134201620

Huerta de Soto, J. (2006). Money, Bank Credit and Economic Cycles. Auburn: Ludwig von Mises Institute.

Huerta de Soto, J. (2008). Financial Crisis and Recession. Mises Daily. https://mises.org/library/financial-crisis-and-recession

Huerta de Soto, J. (2009). El error fatal de Ben Bernanke. Procesos de Mercado: Revista Europea de Economía Polítíca, 6, 233-236.

Hülsmann, G. (2002). Deflation and Liberty. AuburnL Ludwig von Mises Institute.

Hülsmann, G. (2011). The Economics of Deflation. Paper presented at the Ludwig von Mises Institute.

Hume, M., \& Sentence, A. (2009). The Global Credit Boom: Challenges for Macroeconomics and Policy. Journal of International Money and Finance, 28, 1426-1461.

https://doi.org/10.1016/j.jimonfin.2009.08.009

Hummel, J. R. (2011). Ben Bernanke versus Milton Friedman. The Federal Reserve's Emergence as the U.S. Economy's Central Planner. The Independent Review, 15, 485-518.

Hunter, B. (2018). How the Housing Crisis Vindicated the Austrian School of Economics. https://fee.org/articles/how-the-housing-crisis-vindicated-the-austrian-school-of-econ omics/

Karlson, S. (2004). America's Unsustainable Boom. Mises Daily. https://mises.org/library/americas-unsustainable-boom

Keen, S. (2018). The WHO Warns of Outbreak of Virulent New "Economic Reality" Virus. Review of Keynesian Economics, 5, 107-111. https://doi.org/10.4337/roke.2017.01.08

Kornai, J. (1986). The Soft Budget Constraint. Kyklos, 39, 3-30. https://doi.org/10.1111/j.1467-6435.1986.tb01252.x

Krugman P. (1998). The Hangover Theory: Are Recessions Paypack for Good Times? Slate. https://slate.com/business/1998/12/the-hangover-theory.html

Krugman P. (2005). Running out of Bubbles. New York Times.

Latsos, S. (2019). The Low Interest Policy and the Household Saving Behavior in Japan. Working Paper No. 159, Leipzig: University of Leipzig.

Leijonhufvud, A. (2009). Out of the Corridor: Keynes and the Crisis. Cambridge Journal of Economics, 33, 741-757. https://doi.org/10.1093/cje/bep022

Machlup, F. (1974). Friedrich von Hayek's Contributions to Economics. Swedish Journal 
of Economics, 76, 498-531. https://doi.org/10.2307/3439255

Mayer, T., \& Schnabl, G. (2019). Reasons for the Demise of Interest: Savings Glut and Secular Stagnation or Central Bank Policy? Flossbach von Storch Research Institute Working Paper: Macroeconomics 30/10/2019. https://doi.org/10.2139/ssrn.3478451

McKinnon, R. (1973). Money and Capital in Economic Development. Washington DC: Brookings Institution Press.

Meltzer, A. H. (2009). Reflections on the Financial Crisis. Cato Journal, 29, 25-30.

Menger, C. (1871/2004). Principles of Economics (4th ed.). Auburn: Ludwig von Mises Institute.

Mises, L. (1912/1934). The Theory of Money and Credit. New Haven, CT: Yale University Press.

Mises, L. (1949). Human Action. A Treatise on Economics. New Haven, CT: Yale University Press.

Palmer, T. G. (2009). Norberg on the Financial Crisis... Great! http://www.tomgpalmer.com/2009/11/01/norberg-on-the-financial-crisis-great/

Polleit, T. (2007). Manipulating the Interest Rate: A Recipe for Disaster. Mises Daily. https://mises.org/library/mises-daily-articles

Polleit, T. (2019). Why This Boom Could Keep Going Well beyond 2019. Mises Daily. https://mises.org/library/mises-daily-articles

Polleit, T. (2020). The Era of Boom and Bust Isn't Over. Mises Daily. https://mises.org/library/mises-daily-articles

Quiggin, J. (2009). Austrian Business Cycle Theory. https://johnquiggin.com/2009/05/03/austrian-business-cycle-theory/

Ravier, A., \& Lewin, P. (2012). The Subprime Crisis. The Quarterly Journal of Austrian Economics, 15, 45-74.

Reinhart, C. M., \& Rogoff, K. S. (2009). This Time Is Different. Eight Centuries of Financial Folly. Princeton, NJ: Princeton University Press. https://doi.org/10.1515/9781400831722

Rothbard, M. N. (1962/2004). Man, Economy and State: A Treatise on Economic Principles with Power and Market, Government and the Economy. Auburn: Ludwig von Mises Institute..

Rothbard, M. N. (1963/2000). America’s Great Depression (5th ed.). Auburn: Ludwig von Mises Institute.

Salerno, J. T. (2003). An Austrian Taxonomy of Deflation-With Application to the U.S. The Quarterly Journal of Austrian Economics, 6, 81-104. https://doi.org/10.1007/s12113-003-1007-1

Salerno, J. T. (2012). A Reformulation of the Austrian Business Cycle Theory in Light of the Financial Crisis. The Quarterly Journal of Austrian Economics, 15, 3-44. https://doi.org/10.2139/ssrn.1974196

Schnabl, G. (2017). The Failure of ECB Monetary Policy from a Mises-Hayek Perspective. CESifo Working paper No. 6388.

Schwartz, A. J. (2009). Origins of the Financial Market Crisis 2008. Cato Journal, 29, 19-23.

Seeking Alpha (2019). The Unending Artificial Boom. https://seekingalpha.com/article/4312079-unending-artificial-boom

Shaw, E. (1973). Financial Deepening and Economic Development. Oxford: Oxford University Press. 
Shostak, F. (2003). Housing Bubble: Myth or Reality? Mises Daily.

https://mises.org/library/housing-bubble-myth-or-reality

St. Oppers, E. (2002). The Austrian Theory of Business Cycles: Old Lessons for Modern Economic Policy? IMF Working Paper WP/02/2. https://doi.org/10.5089/9781451841770.001

Stiglitz, J. E. (2011). Rethinking Macroeconomics: What Failed, and How to Repair It. Journal of the European Economic Association, 9, 591-645. https://doi.org/10.1111/j.1542-4774.2011.01030.x

Summers, L. (2014). U.S. Economic Prospects: Secular Stagnation, Hysteresis, and the Zero-Lower Bound. Business Economics, 49, 65-73. https://doi.org/10.1057/be.2014.13

Taylor, J. B. (1993). Discretion versus Policy Rules in Practice. Carnegie-Rochester Conference Series on Public Policy, 39, 195-214. https://doi.org/10.1016/0167-2231(93)90009-L

Taylor, J. B. (2009). Getting off Track. Stanford, CA: Hoover Institute Press.

Thornton, M. (2003). Apoplithorismosphobia. The Quarterly Journal of Austrian Economics, 6, 5-18. https://doi.org/10.1007/s12113-003-1001-7

Thornton, M. (2018). The Skyscraper Curse and How Austrian Economics Predicted Every Major Economic Crisis of the Last Century. Auburn: Mises Institute.

Van den Hauwe, L. (2016). Understanding Financial Instability: Minsky versus the Austrians. Journal des Économistes et des Études Humaines, 22, 25-60. https://doi.org/10.1515/jeeh-2016-0008

von Böhm-Bawerk, E. (1890/1959). Capital and Interest. South Holland, IL: Libertarian Press:

White, W. R. (2006). Is Price Stability Enough? BIS Working Papers No. 205. https://doi.org/10.2139/ssrn.900074

Wicksell, K. (1898/1936). Interest and Prices. London: Macmillan.

Wieser, F. (1926/1927). Social Economics. New York: Adelphi Company,

Young, A. T. (2012/2015). Austrian Business Cycle Theory: A Modern Appraisal. In C. J. Coyne, \& P. J. Boettke (Eds.), The Oxford Handbook of Austrian Economics. Oxford: Oxford University Press. https://doi.org/10.1093/oxfordhb/9780199811762.013.9 


\section{Appendix}

Cachanosky and Padilla (2016b) developed a mathematical version of Garrison's (2001) model of canonical ABCT. This is presented briefly below. The model consists of four (five) structural equations which for the sake of simplicity are specified as linear equations.

$$
\begin{gathered}
I^{D}=A-\alpha i \\
I^{S}=B+\beta i \\
I_{\Delta C}^{S}=B+\Delta C R+\beta i \\
Y=C+I \\
C=i \tau
\end{gathered}
$$

Here $I^{D}$ and $I^{S}$ denote the demand for (investment) and supply of (savings) loanable funds, respectively. $i$ is the interest rate in the loanable funds market. This should be interpreted as a rate representing the market yield curve. As usual, investment depends negatively on the interest rate whereby $\alpha>0$ represents the interest-rate elasticity of investment and $A>0$ the interest-rate inelastic intercept of the demand for loanable funds. The supply of loanable funds $I^{S}$ depends positively on the interest rate whereby $\beta>0$ depicts the interest-rate elasticity of savings, and $B>0$ (with $A>B$ ) the interest-rate inelastic intercept of the supply of loanable funds. $Y$ is the value of aggregate output, and is divided between consumption $C$ and aggregate investment $I . \tau$ depicts the length of the base of the Hayekian triangle measuring the total period of production (TPP). The hypotenuse of Hayek's triangle is represented by equation (A.5) and has a zero intercept and slope i. As Cachanosky and Padilla (2016b: p. 229) point out the hypotenuse does not measure pure time but value-time. Because the triangle assumes a constant flow of value-time, von Böhm-Bawerk's $(1890,1959)$ average period of production (APP) is located in the middle of the base of the triangle.

Assuming that the value of total output $Y$ equals the value of potential output $\bar{Y}$, i.e. $Y=\bar{Y}$ and that the loanable-funds market is cleared, i.e. $I^{D}=I^{S}$, equations (A.1)-(A.2) and (A.4)-(A.5) can be solved for the unknowns $i^{*}, I^{*}, C^{*}, \tau^{*}$, whereby the superscript ${ }^{*}$ denotes the market equilibrium values in the absence of (central) bank intervention.

$$
\begin{gathered}
i^{*}=\frac{A-B}{\alpha+\beta} \\
I^{*}=\frac{\beta A+\alpha B}{\alpha+\beta} \\
C^{*}=\bar{Y}-\frac{\beta A+\alpha B}{\alpha+\beta}=\frac{(\alpha+\beta) \bar{Y}-(\beta A+\alpha B)}{\alpha+\beta} \\
\tau^{*} \equiv T P P=\frac{(\alpha+\beta) \bar{Y}-(\beta A+\alpha B)}{A-B}
\end{gathered}
$$




$$
A P P=\frac{1}{2}\left[\frac{(\alpha+\beta) \bar{Y}-(\beta A+\alpha B)}{A-B}\right]
$$

When the banking system intervenes in the market for loanable funds the equilibrium solution denoted as $i_{\triangle C R}^{*}, I_{\triangle C R}^{*}, C_{\triangle C R}^{*}, \tau_{\triangle C R}^{*}, A P P_{\triangle C R}$ reads as follows:

$$
\begin{gathered}
i_{\Delta C R}^{*}=\frac{A-B-\Delta C R}{\alpha+\beta}, \\
I_{\Delta C R}^{*}=\frac{\beta A+\alpha B+\alpha \Delta C R}{\alpha+\beta}, \\
C_{\Delta C R}^{*}=\frac{(\alpha+\beta) \bar{Y}-(\beta A+\alpha B)-\alpha \Delta C R}{\alpha+\beta}, \\
\tau_{\Delta C R}^{*}=\frac{(\alpha+\beta) \bar{Y}-(\beta A+\alpha B)-\alpha \Delta C R}{A-B-\Delta C R} . \\
A P P_{\Delta C R}=\frac{1}{2}\left[\frac{(\alpha+\beta) \bar{Y}-(\beta A+\alpha B)-\alpha \Delta C R}{A-B-\Delta C R}\right]
\end{gathered}
$$

The difference between the market equilibrium solutions with intervention and without intervention can be calculated as follows:

$$
\begin{gathered}
i_{\Delta C R}^{*}-i^{*}=-\frac{1}{\alpha+\beta} \Delta C R, \\
I_{\Delta C R}^{*}-I^{*}=\frac{\alpha}{\alpha+\beta} \Delta C R, \\
C_{\Delta C R}^{*}-C^{*}=-\frac{\alpha}{\alpha+\beta} \Delta C R, \\
\tau_{\Delta C r}^{*}-\tau^{*}=\frac{(\alpha+\beta)(\bar{Y}-A) \Delta C R}{(A-B)(A-B-\Delta C R)} .
\end{gathered}
$$

Supposing that $i_{\Delta C r}^{*}$ prevails we calculate the values for the market with no further bank intervention. The market equilibrium values in response to $i_{\triangle C r}^{*}$ are denoted as $i_{p r}^{*}, I_{p r}^{*}, C_{p r}^{*}, \tau_{p r}^{*}, A P P_{p r}$, whereby $i_{p r}^{*}$ is the implicit rate that holds at the demand for loanable funds given the private supply of funds at $i_{\triangle C r}^{*}$ :

$$
\begin{gathered}
I_{p r}^{S}=B+\beta i_{\Delta C R}^{*}=B+\beta \frac{A-B-\Delta C R}{\alpha+\beta}=\frac{\beta A+\alpha B-\beta \Delta C R}{\alpha+\beta} . \\
I_{p r}^{*}=\frac{(\beta A+\alpha B)-\beta \Delta C R}{\alpha+\beta} \\
i_{p r}^{*}=\frac{(A-B) \alpha+\beta \Delta C R}{\alpha(\alpha+\beta)} \\
C_{p r}^{*}=\frac{(\alpha+\beta) \bar{Y}-(\beta A+\alpha B)+\beta \Delta C R}{\alpha+\beta} \\
\tau_{p r}^{*}=\frac{\alpha[(\alpha+\beta) \bar{Y}-(\beta A+\alpha B)+\beta \Delta C R]}{\alpha(A-B)+\beta \Delta C R}
\end{gathered}
$$




$$
A P P_{p r}=\frac{1}{2} \tau_{p r}^{*}
$$

The deviations of private market reactions from the intervention-free base can be calculated as follows:

$$
\begin{gathered}
I_{p r}^{*}-I^{*}=-\frac{\beta}{\alpha+\beta} \Delta C R, \\
i_{p r}^{*}-i^{*}=\frac{\beta \Delta C R}{\alpha(\alpha+\beta)}, \\
C_{p r}^{*}-C^{*}=\frac{\beta}{\alpha+\beta} \Delta C R, \\
\tau_{p r}^{*}-\tau^{*}=\frac{A-B-(\alpha+\beta) \bar{Y}+\beta A+\alpha B}{(A-B)[\alpha(A-B)+\beta \Delta C R]} .
\end{gathered}
$$

In line with Garrison (2001), and in contradistinction to Young (2012/2015), Cachanosky and Padilla (2016b: p. 241) assert that the credit expansion by the banking system pushes the economy beyond the production possibility frontier by the amount $\triangle C R$, the latter being split into deviations in investment and deviations in consumption.

$$
\begin{gathered}
Y_{\Delta C R}=\bar{Y}+\Delta C R \\
\Delta C R=\left(C_{\Delta C R}^{*}-C^{*}\right)+\left(I_{\Delta C R}^{*}-I^{*}\right)
\end{gathered}
$$

Finally, we calculate the difference between the values of endogenous variables affected by $\triangle C R$ and the private market responses to credit expansion.

$$
\begin{gathered}
i_{\Delta C R}^{*}-i_{p r}^{*}=-\frac{1}{\alpha} \Delta C R \\
I_{\Delta C R}^{*}-I_{p r}^{*}=\Delta C R \\
C_{\Delta C r}^{*}-C_{p r}^{*}=-\Delta C R \\
\tau_{\Delta C R}^{*}-\tau_{p r}^{*}=\Delta C R \frac{(\alpha+\beta)\left[(\alpha+\beta) Y_{\Delta C R}-\alpha(A-B-\Delta C R)\right]+\beta A+\alpha B-2 \alpha \beta \Delta C R}{(A-B-\Delta C R)[\alpha(A-B)+\beta \Delta C R]}
\end{gathered}
$$

Since there are two interest rates, i.e. $i_{\Delta C R}^{*}$ and $i_{p r}^{*}$ we encounter two Hayekian triangles. Hereby, $i_{\Delta C R}^{*}$ determines the slope of the hypotenuse of the Hayekian triangle for early stages of production, while the rate $i_{p r}^{*}$ defines the slope of the hypotenuse for late stages of production. Where the two Hayekian triangles intersect (i.e. where the Hayekian triangle 'breaks') the value of $\tau$, denoted as $\tau_{b r}$, can be calculated as follows:

$$
C_{b r}=\left(\tau_{\Delta C R}-\tau_{b r}\right) i_{\Delta C R}=\left(\tau_{p r}-\tau_{b r}\right) i_{p r}=C_{b r} .
$$

Solving (A.35) for $\tau_{b r}$ gives the following result:

$$
\tau_{b r}=\frac{\tau_{p r} i_{p r}-\tau_{\Delta C R} i_{\Delta C R}}{i_{p r}-i_{\Delta C R}}=\alpha .
$$


Insertion of $\tau_{b r}$ from (A.36) into (A.35) finally results in the following:

$$
C_{b r}=\frac{(\alpha+\beta)(\bar{Y}-A)-(\beta A+\alpha B)}{\alpha+\beta}<C_{\Delta C R}^{*}<C_{p r}^{*} .
$$

